\title{
Redox stable anodes for solid oxide fuel cells
}

\author{
Guoliang Xiao and Fanglin Chen* \\ Department of Mechanical Engineering, University of South Carolina, Columbia, SC, USA
}

Edited by:

Jinliang Yuan, Lund University,

Sweden

Reviewed by:

Chao Xu, North China Electric Power University, China

Shaorong Wang, Chinese Academy of Sciences, China

*Correspondence:

Fanglin Chen, Department of

Mechanical Engineering, University of

South Carolina, 300 Main Street,

Columbia, SC 29208, USA

e-mail: chenfa@cec.sc.edu
Solid oxide fuel cells (SOFCs) can convert chemical energy from the fuel directly to electrical energy with high efficiency and fuel flexibility. Ni-based cermets have been the most widely adopted anode for SOFCs. However, the conventional Ni-based anode has low tolerance to sulfur-contamination, is vulnerable to deactivation by carbon build-up (coking) from direct oxidation of hydrocarbon fuels, and suffers volume instability upon redox cycling. Among these limitations, the redox instability of the anode is particularly important and has been intensively studied since the SOFC anode may experience redox cycling during fuel cell operations even with the ideal pure hydrogen as the fuel. This review aims to highlight recent progresses on improving redox stability of the conventional Ni-based anode through microstructure optimization and exploration of alternative ceramic-based anode materials.

Keywords: solid oxide fuel cells, anode, redox stability, microstructure, ceramic anode, catalyst

\section{INTRODUCTION}

Solid oxide fuel cells (SOFCs) are promising energy conversion devices. Elevated operating temperatures (typically in the range of $400-1000^{\circ} \mathrm{C}$ ) of SOFCs promote electrochemical reactions at the electrodes, eliminating the need of precious metal catalysts. Furthermore, they are capable of operating on hydrocarbon fuels directly; they can function in electrolysis mode for energy storage with excellent reversibility; they are modular, scalable, and silent. These features make SOFCs ideal solution for a wide spectrum of power needs such as stationery power supplies, auxiliary power units, and portable power devices (Singhal, 2003; Huang and Goodenough, 2009).

Solid oxide fuel cells typically have three major components, a dense electrolyte sandwiched between two porous electrodes: anode and cathode. The conventional cell materials are yttriastabilized zirconia (YSZ) electrolyte, Ni-YSZ cermets anode, and strontium-doped lanthanum manganite (LSM) cathode, respectively (Zhu and Deevi, 2003b; Kharton et al., 2004; Sun and Stimming, 2007; Jiang, 2008). In order to minimize high ohmic loss from the YSZ electrolyte due to its limited oxide ion conductivity, thin electrolyte membranes are widely applied (de Souza et al., 1997). Given the consideration of mechanical strength of the cells, a supported structure is often required in these SOFCS with thin electrolyte membranes. Ni-YSZ cermet anode, consisting of a significant volume ratio of $\mathrm{Ni}$ metal phase to meet the requirement for electronic conductivity and an YSZ phase for ionic conduction, has excellent electrical conductivity, good mechanical strength, and excellent electrochemical activity in $\mathrm{H}_{2}$ and even hydrocarbon fuels. Furthermore, Ni-YSZ cermet anode is cost effective and easy to fabricate. Therefore, anode-supported cells are widely adopted. However, the $\mathrm{Ni}$ metal phase in conventional Ni-YSZ anodes causes several issues for SOFCs under practical conditions, such as carbon deposition in hydrocarbon fuels and poisoning by trace amount of impurities from the fuel such as sulfur-containing species (Oudar, 1980; Matsuzaki and Yasuda, 2000; Takeguchi et al., 2002; Haga et al., 2008a,b). One of the most important limitations for Ni-based cermet anode is the poor stability in redox cycling, primarily due to the large volume change and coarsening of the Ni-phase in the cermet anode (Klemensø et al., 2006; Klemenso and Mogensen, 2007; Sarantaridis and Atkinson, 2007; Monzon and Laguna-Bercero, 2012). Ni experiences 69.9\% volume increase upon oxidation to $\mathrm{NiO}$. Such large volume change of $\mathrm{Ni}$-phase will produce considerable stress in the anode and electrolyte. When the porosity in the Ni-YSZ anode cannot accommodate the volume change, the rigid YSZ network can be broken and the whole cell may even fail. Additionally, such redox cycles can be expected while fuel cells are under long-term operation, mainly due to unexpected fuel supply interruption, high fuel utilization under high current load, or gas sealing failure. Although there have been several SOFC system solutions proposed for preventing such circumstances, they will add complexity and extra cost to the SOFC system, and the accidental operation failure is still a concern. Therefore, it is more desirable to avoid the potential cell failure by improving the redox stability of anodes.

The reduction and oxidation processes for $\mathrm{Ni}$ and the impact of redox cycling on mechanical properties, electrical conductivity, and electrochemical performance of Ni-cermet anodes have been intensively reviewed (Sarantaridis and Atkinson, 2007; Ettler et al., 2010; Faes et al., 2012). This review intends to highlight recent progresses on improving redox stability of SOFC anodes, including modifications to Ni/YSZ cermet anodes and overview of some newly proposed ceramic materials/ceramic composite materials as potential redox capable SOFC anodes.

\section{NI-CERMET ANODES}

The impact of redox cycling on $\mathrm{Ni}$-cermet anodes has been well investigated. Reduction was found to have no significant dimensional influence on $\mathrm{NiO} / \mathrm{YSZ}$ bulk ceramic, indicating the supporting role of the YSZ network (Fouquet et al., 2003). The mechanical strength of $\mathrm{NiO}(56 \mathrm{wt} \%) / \mathrm{YSZ}$ substrate was measured by GrahlMadsen et al. (2006) via the four points bending tests. The mean modulus of rupture only dropped slightly from 20.3 to $17.5 \mathrm{MPa}$, 
suggesting that the strength of the reduced cermet relies on the sintered YSZ network. However, the electrical conductivity was significantly affected by the reduction temperature (Grahl-Madsen et al., 2006). An almost linear relationship between the electrical conductivity and reduction temperature was reported. Higher conductivity was obtained after the substrates were reduced at higher temperature, but the low conductivity of the substrates reduced at lower temperature could not be improved significantly by additional treatment at higher temperature. This may be attributed to simultaneous reduction and sintering of Ni (Sarantaridis and Atkinson, 2007). On the other hand, significant volume increase after re-oxidation was observed by Cassidy et al. (1996) compared to the initial state. The authors explained that the large volume change upon re-oxidation followed by the simultaneous reduction and sintering for $\mathrm{Ni}$ might exceed the accommodation provided by the porosity. Based on modeling study, Klemensø et al. (2005) suggested that the reorganization of the $\mathrm{Ni} / \mathrm{NiO}$ phase during reduction and re-oxidation account for the redox instability of the anode and that the oxide growth cause damage to the YSZ network. The redox impact on microstructure of a Ni/YSZ anodesupported cell has been intuitively demonstrated by a sequence of SEM images which focus on exactly the same location during redox cycling by Malzbender and Steinbrech (2007). Figure 1A shows the initial dense $\mathrm{NiO}$ particles in the anode after sintering. Upon reduction, the Ni particles shrank evidently and the porous anode

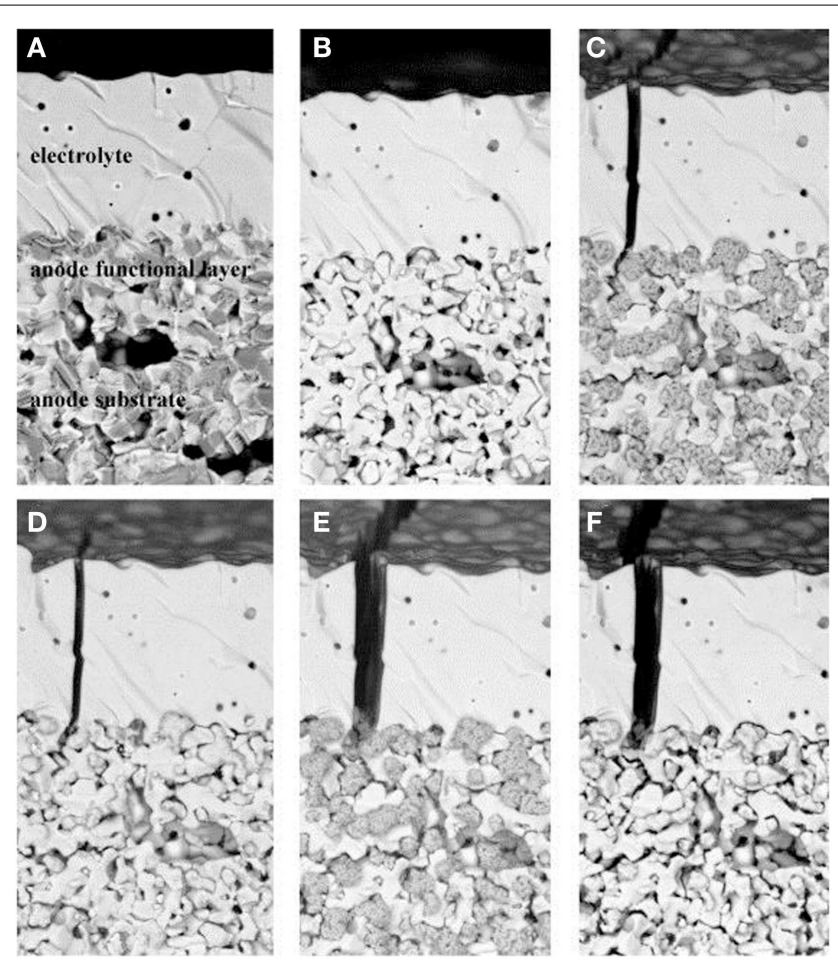

FIGURE 1 | SEM study of microstructural changes in anode and anode substrate due to reduction/re-oxidation cycles. (A) Initial as co-fired state, (B) reduced, (C) re-oxidized, (D) re-reduced, (E) re-re-oxidized, (F) re-re-reduced with additional holding time of $100 \mathrm{~h}$ (Malzbender and Steinbrech, 2007). Reprinted with permission from Elsevier. was generated as shown in Figure 1B. However, the microstructure of $\mathrm{NiO}$ cannot be restored after re-oxidation. Figure $1 \mathrm{C}$ shows that sponge-like $\mathrm{NiO}$ particles were formed during re-oxidation, consistent with the outward growth nature of $\mathrm{NiO}$ on $\mathrm{Ni}$ (Atkinson, 1987; Sarantaridis and Atkinson, 2007). The volume of the porous $\mathrm{NiO}$ after re-oxidation was evidently larger than that in the initial state, which caused micro cracks in the anode and even the fracture in the electrolyte. When the anode was reduced again, dense $\mathrm{NiO}$ particles were formed as shown in Figure 1D, but the particle size became larger and the structure became coarser comparing with that shown in Figure 1B. Additional oxidation aggravated the microstructure changes that the electrolyte crack opened larger and the $\mathrm{NiO}$ particles appeared to be even more fragmented (Figure 1E). However, additional reduction did not cause further deteriorative changes in the microstructure of the anode as shown in Figure 1F, in which the anode microstructure after another reduction with an additional holding time of $100 \mathrm{~h}$ looked similar to the re-reduced case (Figure 1D).

Since the cracks in the electrolyte are caused by volume expansion of the Ni-YSZ anode support, there seems to be a critical expansion limit for the support to prevent electrolyte failure. It has been established by mechanical modeling that anode-supported SOFCs can withstand about $0.1-0.2 \%$ expansion of the supporting composite during redox cycling without cracking (Laurencin et al., 2008; Pihlatie et al., 2009). For electrolyte-supported cell configuration, an oxidation strain of $0.5 \%$ for a $10 \mu \mathrm{m}$-thick anode layer can be tolerated (Thouless, 1991). With this target, several solutions have been proposed for improving redox tolerance of $\mathrm{Ni} / Y S Z$ supported cells.

\section{MICROSTRUCTURAL OPTIMIZATION}

The redox behavior of Ni-cermet anode seems to be affected significantly by the microstructure of Ni/YSZ and improvements can be made through optimization in the Ni/YSZ microstructure and composition (Wood et al., 2006). Itoh et al. (1997) investigated the impact of the particle distribution of YSZ powders on microstructural stability of Ni/YSZ anodes. Coarse $(\sim 27.0 \mu \mathrm{m})$ and fine $(\sim 0.6 \mu \mathrm{m})$ YSZ powders were mixed to fabricate Ni/YSZ anodes. Comparing to uniform-sized YSZ in conventional Ni/YSZ anodes, no significant dimension and microstructure changes of the new anodes were detected during sintering in air and reduction in a reducing atmosphere, which was attributed to the optimized microstructure of YSZ frame. They also found that good longterm stability cannot be achieved by making the anode with the coarse YSZ particles alone, and additional fine YSZ particles could help achieve more stable anodes without substantial decrease in electrical conductivity and change in anode microstructure. The function of the coarse YSZ particles is to form a porous and loose frame work, which allows $\mathrm{Ni}$ agglomeration to form sufficient electronic conducting path, and the fine YSZ particles function as inhibitor to prevent $\mathrm{Ni}$ agglomeration and form connections between coarse YSZ particles. The conductivity of the Ni-cermets anode has been found to depend not only on the Ni content but also on the particle size of YSZ and the mixture ratio between the coarse and the fine YSZ.

Fouquet et al. (2003) studied the influence of $\mathrm{NiO}$ and YSZ particle sizes and sintering temperatures on dimensional changes 
of $\mathrm{NiO} / Y S Z$ bulk ceramics and found that smaller size of initial $\mathrm{NiO}$ particles and lower sintering temperature were beneficial for improving redox stability. The particle size distribution of $\mathrm{NiO}$ was found to be a very effective factor. Lower length expansion of the bar samples was observed with finer $\mathrm{NiO}$ particles. The benefit from lower sintering temperatures was attributed to the less rigid YSZ network and higher porosity to better compensate volume changes of Ni upon redox cycling.

Kim et al. (2006) investigated thermal/redox cycling stability of $\mathrm{NiO} / \mathrm{YSZ}$ composite powder composed of nano-sized $\mathrm{NiO}$ crystallized (20-30 nm, $40 \mathrm{wt} \%)$ on YSZ powder $(0.3$ and $10 \mu \mathrm{m}$, $60 \mathrm{wt} \%)$ prepared by decomposition of aqueous Ni-based solution. The anode made from NiO/YSZ composite powder, which had a high homogeneity and plenty of contact sites between $\mathrm{Ni}$ and YSZ, exhibited an excellent tolerance against thermal and redox cycling. The electrical conductivity decreased by $10 \%$ from 1450 to $1250 \mathrm{~S} \mathrm{~cm}^{-1}$ over 20 redox cycles at $800^{\circ} \mathrm{C}$, while the conductivity for the conventional $\mathrm{NiO}-\mathrm{YSZ}$ mixing powder decreased by $47 \%$ from 1200 to $600 \mathrm{~S} \mathrm{~cm}^{-1}$ (Figure 2). They concluded that the functional $\mathrm{NiO} / \mathrm{YSZ}$ composite powder would suppress the degradation of anodes and enhance the long-term redox stability of the cells at elevated temperatures.

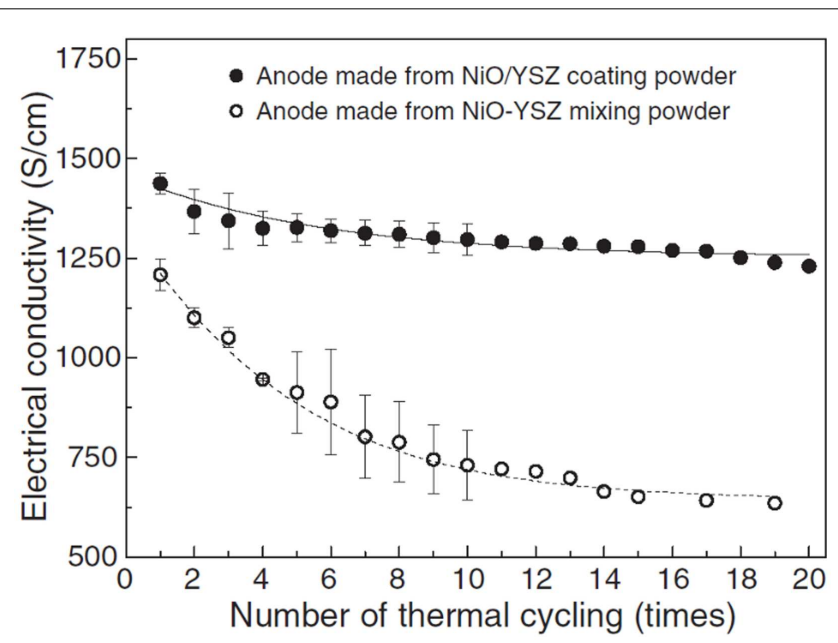

FIGURE 2 | Electrical conductivity variations of anodes depending on thermal cycling (Kim et al., 2006). Reprinted with permission from Elsevier.
Waldbillig et al. (2005) found that anode samples with coarse microstructure experienced no volume change or cracking upon redox cycling. Fine structured anode samples did not change in volume after reduction, but expanded between 0.9 and $2.5 \%$ after oxidation. The samples were significantly cracked after oxidation. The amount of expansion and cracking could be reduced by lowering the Ni content of the anode (Ettler et al., 2010). However, the Ni content in the substrate must be sufficient to meet the requirement for electronic conductivity. Waldbillig et al. fabricated graded anode functional layer to gradually decrease the $\mathrm{Ni}$ content near the electrolyte membrane (Figure 3A). The redox tolerance of the cells was evidently improved when the Ni content was lowered. They also added an oxidation barrier layer with finer microstructure to the bottom of the cell to restrict the oxygen flowing into the anode (Figure 3B). Both types of microstructural modification effectively improved the cell redox tolerance compared with standard baseline redox tests (Waldbillig et al., 2007). Although the cell tolerance to a certain depth of oxidation was enhanced, the stability of the cells in multiple redox cycles may be problematic for these solutions.

By performing dilatometric measurements, Pihlatie et al. (2009) found that highly porous samples were most stable in redox cycling. The cumulative redox strain, $\mathrm{d} L / L_{0}$, increased significantly when the as-sintered porosity decreased from 34 to $9 \%$ as shown in Figure 4. The most stable cermets showed a maximum cumulative redox strain not exceeding $0.1 \%$ during three redox cycles at $850^{\circ} \mathrm{C}$. Electrochemical testing on Ni-Sc YSZ symmetrical cells showed that isothermal redox cycling at $850^{\circ} \mathrm{C}$ did not significantly alter the electrode performance and improvement in the electrochemical performance of the anode on low temperature redox cycling was observed. Such improvement was attributed to small $\mathrm{Ni}$ grains and an undamaged ceramic structure observed in the sample redox-cycled at lower temperature.

\section{NI-INFILTRATED YSZ ANODES}

The investigations on microstructural modifications for Ni-based cermet suggest that better redox stability can be achieved with a robust YSZ network, which can tolerate the expansion of Ni during oxidation to form fine $\mathrm{NiO}$ particles (Fouquet et al., 2003). The conventional Ni-based cermet anodes have to go through high-temperature sintering process which inevitably coarsens $\mathrm{NiO}$ particles. Infiltration is considered an efficient method to achieve this desired microstructure. To apply this fabrication technique,
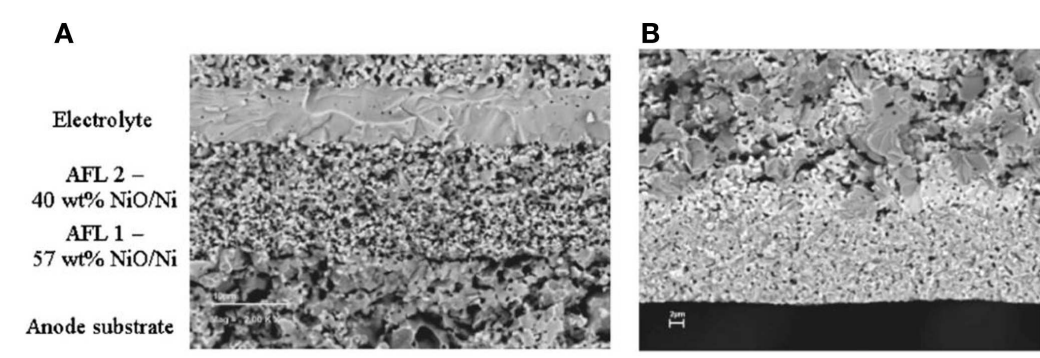

Anode

substrate

Oxidation

barrier

FIGURE 3 | BSE SEM images of (A) a reduced fuel cell with a graded anode functional layer, (B) an as-prepared 57 wt $\%$ NiO oxidation barrier (Waldbillig et al., 2007). Reprinted with permission from The Electrochemical Society. 


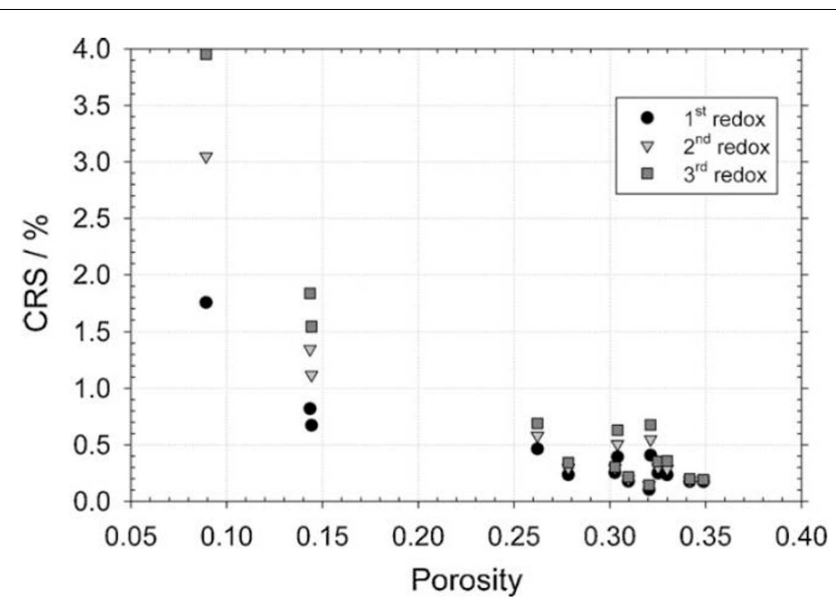

FIGURE 4 | Maximum cumulative redox strain (CRSmax) values obtained in isothermal redox cycling dilatometry comprising three redox cycles, as a function of estimated total porosity of different Ni-YSZ cermets (Pihlatie et al., 2009). Reprinted with permission from Elsevier.

porous YSZ substrates are usually pre-sintered at high temperatures to form rigid networks. Aqueous Ni-based salt solution is subsequently infiltrated into the porous YSZ substrates and then treated at a relatively low temperature to form $\mathrm{NiO}$. Nano-sized $\mathrm{Ni}$ particles coated on porous YSZ substrates can be obtained through such low temperature decomposition and in situ reduction. Additionally, compared with the conventional cermet anodes, a less amount of $\mathrm{NiO}$ is required for the infiltrated anode to meet the electronic conductivity requirement (the Ni percolation threshold of $30 \mathrm{vol} \%$ ), since Ni network can be efficiently formed by nanosized particles on YSZ surface. Reducing Ni content may mitigate the redox issues for Ni-based cermets. Based on these advantages, Ni-infiltrated YSZ cermets were considered as a possible solution for the redox problem.

Busawon et al. (2008) investigated Ni infiltration into porous YSZ structures as a possible solution to the redox degradation of Ni-based SOFC anodes and anode supports. The cermets containing $12-16 \mathrm{wt} \% \mathrm{Ni}$ prepared by infiltration exhibited conductivity above $300 \mathrm{~S} \mathrm{~cm}^{-1}$ at room temperature. Its conductivity dropped by $20 \%$ after one redox cycle, but it was not accompanied by bulk dimensional changes. The dimensional stability was also attributed to the microstructure of the infiltrated anode.

Recently, redox stable SOFCs with Ni-YSZ cermet anodes ( $30 \mathrm{vol} \% \mathrm{NiO}$ ) prepared by infiltration method were reported by Buyukaksoy et al. (2012). They infiltrated polymeric NiO precursor into a porous YSZ layer $(\sim 10 \mu \mathrm{m}$ thick) pre-sintered on a $170 \mu \mathrm{m}$-thick electrolyte supporting membrane. A Ni-YSZ cermet consisted of porous YSZ coated by nano-sized Ni particles was obtained. Furthermore, benefited from the low-temperature processing, internal stress between the $\mathrm{Ni} / \mathrm{NiO}$ and the YSZ substrate was low during the redox cycling. The power density of the SOFCs degraded less than 1\% after 15 cycles as shown in Figure 5.

The Ni-cermet anodes prepared by infiltration methods exhibit enhanced redox stability, but the long-term stability of small $\mathrm{Ni}$

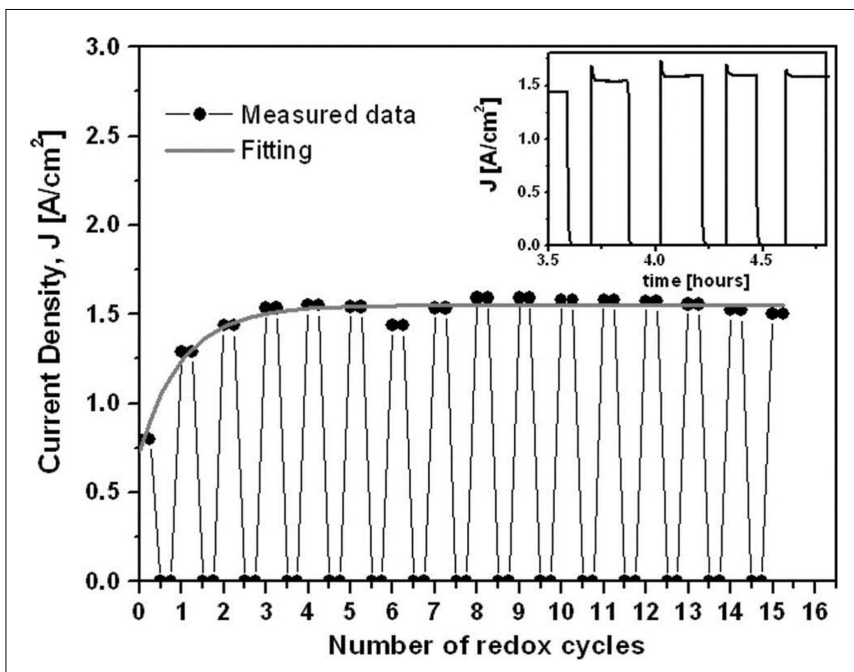

FIGURE 5 | Influence of redox cycles on the current density at short circuit conditions at $\mathbf{8 0 0}^{\circ} \mathbf{C}$. The inset graph shows the change in short circuit current density in time between 7 th and 10 th redox cycles at $800^{\circ} \mathrm{C}$ (Buyukaksoy et al., 2012). Reprinted with permission from The Electrochemical Society.

particles at SOFC operation temperatures is questionable since coarsening of Ni particles may cause degradation in cell performance and in turn weaken redox tolerance. Some low surface energy oxides such as $\mathrm{MgO}, \mathrm{TiO}_{2}, \mathrm{Mn}_{3} \mathrm{O}_{4}$, and $\mathrm{Cr}_{2} \mathrm{O}_{3}$ were added to the anode cermet to suppress Ni coarsening (Tsoga et al., 1996; Zhu and Deevi, 2003b). These additives were expected to retard the coarsening of Ni particles during the high-temperature operation of cells, improve the mechanical properties of anode by assisting in the sintering of YSZ, and enhance the wettability of Ni particles by acting as anchoring sites at the anode/electrolyte interface. Tikekar et al. (2006) further investigated reduction and re-oxidation kinetics of Ni-YSZ cermet with and without small amount of oxide additives $\left(4 \mathrm{~mol} \%\right.$ of $\mathrm{CaO}, \mathrm{MgO}$, and $\mathrm{TiO}_{2}$ ) and found that the oxide additives were effective to suppress the kinetics of both reduction and re-oxidation, although by different mechanisms, thereby improving redox tolerance of Ni-cermet anodes.

Although the infiltration method has been demonstrated as an effective way to improve redox stability of Ni-cermet anodes, implementation of this method in large-scale cell production is still problematic, since it typically requires special care to ensure that infiltration solutions go into the anode substrate pores without flooding and the process often needs to be repeated several times to obtain proper $\mathrm{Ni}$ loading. In general, it is labor-intensive, time-consuming, and costly for applications. Additionally, the redox issues resulting from the Ni-phase is still unresolved. Therefore, substitutions for $\mathrm{Ni}$ are widely investigated as an alternative way to solve the redox issues for SOFCs.

\section{CERAMIC ANODES}

The Ni-phase in Ni-based cermets functions as the electronic conducting phase in the SOFC anode and the substitution materials must meet the requirement for electronic conductivity at the operation conditions. They also should have good chemical 
compatibility with other components used in SOFCs. Alternative transition metals, such as $\mathrm{Cu}, \mathrm{Ni}-\mathrm{Cu}$, and $\mathrm{Ni}-\mathrm{Fe}$, have been considered and some of them have demonstrated better coking resistance than Ni-cermets (Gorte et al., 2002; Kim et al., 2002; Ishihara et al., 2006). However, the redox issue still remains for these metals since they can also be easily oxidized under the typical SOFC operating conditions. Considering the tolerance to oxidation, precious metals should be a good choice. However, they are far more expensive for practical use, especially when significant quantities are needed to meet the electronic conductivity requirement. Some ceramic materials which are stable in a wide range of oxygen partial pressures under SOFC operating conditions may have much smaller volume change, arising from oxygen non-stoichiometry, during redox cycling when compared with the transition metals. They also have considerably lower cost than precious metals. Therefore, electronic conducting ceramic materials have drawn great research interests as alternative SOFC anodes.

As potential SOFC anode materials, suitable ceramic candidates need to meet the following requirements (Goodenough and Huang, 2007; Fu and Tietz, 2008; Ruiz-Morales et al., 2011). (1) Electronic conductivity. It is suggested that the electronic conductivity should be above $1 \mathrm{~S} \mathrm{~cm}^{-1}$ for the functional anode materials. (2) Electrocatalytic activity. Fuels should be well electrochemically oxidized on the materials. (3) Stability. They must be chemically compatible with other contacted components, including electrolytes and current collectors under fabrication and operating conditions. Their electrochemical properties should not degrade upon operation time due to reactions with fuels. (4) Thermal compatibility. The thermal expansion of the materials should match other contacted components to insure good contact during thermal cycling. Many ceramic materials with different structures, including perovskite, fluorite, pyrochlore, and tungsten bronze, have been studied as SOFC anode candidates (Sun and Stimming, 2007). Among them, the $\mathrm{ABO}_{3}$ perovskite-type materials exhibit good stability at high temperatures and tunable properties by adjusting the types and amount of the cations. A lot of perovskite ceramic materials have been studied as anode candidates and some of them have demonstrated promising redox stability.

\section{CHROMITES}

$\mathrm{LaCrO}_{3}$-based perovskite materials are stable and conductive in both reducing and oxidizing atmospheres. They are widely used as interconnect materials and have also been demonstrated as anode candidates (Tao and Irvine, 2003; Zhu and Deevi, 2003a). Since $\mathrm{LaCrO}_{3}$ is a p-type conductor, divalent cations such as $\mathrm{Sr}^{2+}, \mathrm{Ca}^{2+}, \mathrm{Ni}^{2+}$, and $\mathrm{Mg}^{2+}$ are often doped into its $\mathrm{A}$ or $\mathrm{B}$ sites, according to their radii, to enhance its electrical conductivity (Primdahl et al., 2001; Ruiz-Morales et al., 2007a). Tao et al. investigated ( $\mathrm{La}, \mathrm{Sr}) \mathrm{CrO}_{3}$ with $\mathrm{Mn}, \mathrm{Fe}, \mathrm{Co}, \mathrm{Ni}$, and $\mathrm{Cu}$ as B-site dopants, which accept lower coordination numbers and may enhance oxide ion migration. They increased doping ratio to $50 \%$, expecting to increase oxide ionic conductivity by forming a percolation passage for oxide ions (Tao and Irvine, 2003). Due to the structural instability of $\mathrm{Fe}-, \mathrm{Co}-, \mathrm{Ni}-$, and $\mathrm{Cu}$-doped ones under anode conditions, only $\mathrm{La}_{0.75} \mathrm{Sr}_{0.25} \mathrm{Cr}_{0.5} \mathrm{Mn}_{0.5} \mathrm{O}_{3}$ turned out to be a promising redox stable electrode candidate. Its electrical conductivity reached $38 \mathrm{~S} \mathrm{~cm}^{-1}$ in air and $3 \mathrm{~S} \mathrm{~cm}^{-1}$ in wet
$\mathrm{H}_{2}$ at $900^{\circ} \mathrm{C}$. In wet $\mathrm{H}_{2}$, a relatively low polarization resistance of $0.2 \Omega \mathrm{cm}^{-2}$ was also observed for this material. Compared with other $\mathrm{LaCrO}_{3}$-based materials, the enhanced performance for $\mathrm{La}_{0.75} \mathrm{Sr}_{0.25} \mathrm{Cr}_{0.5} \mathrm{Mn}_{0.5} \mathrm{O}_{3}$ was attributed to the potentially enhanced mixed ionic and electronic conduction. Although oxide ionic conductivity is not required for the ceramic anode materials, it is known that the catalytic reaction in the anode can be promoted by extending active sites from three phase boundaries to the anode bulk (Zhang et al., 2013).

Symmetrical SOFC performance and redox stability of $\mathrm{La}_{0.75} \mathrm{Sr}_{0.25} \mathrm{Cr}_{0.5} \mathrm{Mn}_{0.5} \mathrm{O}_{3}$ electrodes have been studied by Bastidas et al. (2006). The polarization resistance of $\mathrm{La}_{0.75} \mathrm{Sr}_{0.25} \mathrm{Cr}_{0.5} \mathrm{Mn}_{0.5} \mathrm{O}_{3}$ electrode was measured on YSZ electrolyte membranes using three-electrode half-cell technique at $900^{\circ} \mathrm{C}$. The cells were stabilized sequentially in humidified hydrogen, reformate, and then humidified oxygen for 30$60 \mathrm{~min}$ in each atmosphere and for four cycles. The polarization resistance exhibited slight degradation after the first cycle, but then became stabilized, indicating remarkable redox stability of $\mathrm{La}_{0.75} \mathrm{Sr}_{0.25} \mathrm{Cr}_{0.5} \mathrm{Mn}_{0.5} \mathrm{O}_{3}$. The symmetrical cell with $\mathrm{La}_{0.75} \mathrm{Sr}_{0.25} \mathrm{Cr}_{0.5} \mathrm{Mn}_{0.5} \mathrm{O}_{3}-\mathrm{YSZ}(70: 30 \mathrm{wt} \%)$ as both anode and cathode on a $200 \mu \mathrm{m}$-thick YSZ electrolyte exhibited maximum power densities of $300 \mathrm{~mW} \mathrm{~cm}^{-2}$ in wet $\mathrm{H}_{2}$ and $230 \mathrm{~mW} \mathrm{~cm}^{-2}$ in wet $\mathrm{CH}_{4}$. Such cells were also demonstrated to function in electrolyzer mode. In order to further improve electrocatalytic activity, $\mathrm{La}_{0.75} \mathrm{Sr}_{0.25} \mathrm{Cr}_{0.5} \mathrm{Mn}_{0.5} \mathrm{O}_{3}-\mathrm{YSZ}-\mathrm{GDC}$ composite electrodes were also investigated in anode and cathode conditions (Ruiz-Morales et al., 2007b). It was found that the anode polarization resistance could be optimized by introducing a certain amount of GDC. The symmetrical SOFCs with an $180 \mu \mathrm{m}$-thick YSZ electrolyte achieved a maximum power density of $0.4 \mathrm{~W} \mathrm{~cm}^{-2}$ in $\mathrm{H}_{2}$ at $950^{\circ} \mathrm{C}$. Microstructure optimization has also been applied to $\mathrm{La}_{0.75} \mathrm{Sr}_{0.25} \mathrm{Cr}_{0.5} \mathrm{Mn}_{0.5} \mathrm{O}_{3}$-based electrodes by using poly (methyl methacrylate) PMMA microspheres as template. The peak power density of symmetrical cell with $\mathrm{La}_{0.75} \mathrm{Sr}_{0.25} \mathrm{Cr}_{0.5} \mathrm{Mn}_{0.5} \mathrm{O}_{3}-\mathrm{YSZ}$ electrodes was improved to 0.5 and $0.3 \mathrm{~W} \mathrm{~cm}^{-2}$ in $\mathrm{H}_{2}$ and $\mathrm{CH}_{4}$, respectively at $950^{\circ} \mathrm{C}$ (Ruiz-Morales et al., 2006a).

$\mathrm{Y}_{0.8} \mathrm{Ca}_{0.2} \mathrm{Cr}_{0.8} \mathrm{Co}_{0.2} \mathrm{O}_{3}-\mathrm{SDC}$ composite has been reported by Yoon et al. (2011) recently as a high performance redox stable ceramic anode for SOFC. The anode in YSZ electrolyte-supported cells exhibited comparable performance in $\mathrm{H}_{2}$ as the Ni/YSZ anode and showed good sulfur tolerance. The linear expansion of $\mathrm{Y}_{0.8} \mathrm{Ca}_{0.2} \mathrm{Cr}_{0.8} \mathrm{Co}_{0.2} \mathrm{O}_{3}$ was less than $0.08 \%$ at $800^{\circ} \mathrm{C}$ when $\mathrm{P}_{\mathrm{O}_{2}}$ changing from 0.21 to $4.5 \times 10^{-19}$ atm and no performance degradation for the cell with $\mathrm{Y}_{0.8} \mathrm{Ca}_{0.2} \mathrm{Cr}_{0.8} \mathrm{Co}_{0.2} \mathrm{O}_{3}-\mathrm{SDC}$ anode was observed after four redox cycles.

\section{TITANATES}

Another interesting perovskite family is $\mathrm{SrTiO}_{3}$-based materials. Reduced donor-doped $\mathrm{SrTiO}_{3}$ can exhibit very high electrical conductivity which is close to or above $100 \mathrm{~S} \mathrm{~cm}^{-1}$ at $800^{\circ} \mathrm{C}$ in reducing atmosphere (Moos and Hardtl, 1996). Due to the suppressed oxygen vacancies and slow $\mathrm{Sr}$ diffusivity, the defect equilibration of donor-doped $\mathrm{SrTiO}_{3}$ materials under different oxygen partial pressures is quite slow, resulting in a strong dependence of electrical conductivity on material treatment history. Without 
equilibration in low $\mathrm{P}_{\mathrm{O}_{2}}$ at high temperature for a sufficiently long time, the electrical conductivity is often quite low (Kolodiazhnyi and Petric, 2005). However, such slow process of equilibration improves tolerance to redox cycling that the high electrical conductivity can be restored after a short period of exposure to air. Consequently, this feature makes the donor-doped $\mathrm{SrTiO}_{3}$ materials potential redox stable anode candidates for SOFCs.

Hui and Petric (2002) reported rapid changes in conductivity of $\mathrm{Sr}_{0.88} \mathrm{Y}_{0.08} \mathrm{TiO}_{3}$ (sintered in $7 \% \mathrm{H}_{2}$ at $1400^{\circ} \mathrm{C}$ ) after a sudden oxygen partial pressure change at $800^{\circ} \mathrm{C}$ from $7 \% \mathrm{H}_{2}$ to air or vice versa. The changes reached a plateau after some time indicating that the processes were diffusion-controlled and the surface reaction at $800^{\circ} \mathrm{C}$ for both oxidation and reduction was fast for this material. The electrical conductivity was found reversible on oxidation and reduction, but the reduction took much longer time, indicating that the incorporation of oxygen into lattice is much easier than the release of oxygen from the lattice. Fu et al. reported that the electrical conductivity change of a porous $\mathrm{Sr}_{0.93} \mathrm{Y}_{0.07} \mathrm{TiO}_{3}$ sample (sintered in $4 \% \mathrm{H}_{2} / \mathrm{Ar}$ at $1300^{\circ} \mathrm{C}$ for $10 \mathrm{~h}$ and then annealed in $\mathrm{Ar}$ at $1100^{\circ} \mathrm{C}$ for $3 \mathrm{~h}$ to simulate the cathode sintering condition, porosity $15 \%$ ) in five redox cycles at $800^{\circ} \mathrm{C}$ (Fu and Tietz, 2008). Only slow degradations were observed. Considering the short recovery time in reducing atmospheres, this material showed good redox tolerance. Recently, Burnat et al. (2012) performed the redox cycling of $\mathrm{La}_{0.2} \mathrm{Sr}_{0.704} \mathrm{TiO}_{3}$ at $800^{\circ} \mathrm{C}$ over a period of $120 \mathrm{~h}$ as shown in Figure 6. Similar behaviors were found after exposing the anode to oxidizing atmosphere for $30 \mathrm{~min}$. One hundred percent of the initial conductivity was restored after $12.5 \mathrm{~h}$ retreatment in reducing atmosphere. This recovery process of conductivity was found fully reproducible under the given experimental conditions. After six cycles, the initial conductivity could still be recovered. Redox stability of $\mathrm{SrNb}_{0.01} \mathrm{Ti}_{0.99} \mathrm{O}_{3}-\mathrm{YSZ}$ composite was also reported by Gross et al. (2009). After two redox cycles at 700 and $800^{\circ} \mathrm{C}$, the conductivity of the porous samples was almost recovered in a short period of time. Interestingly, also due to the slow equilibration in

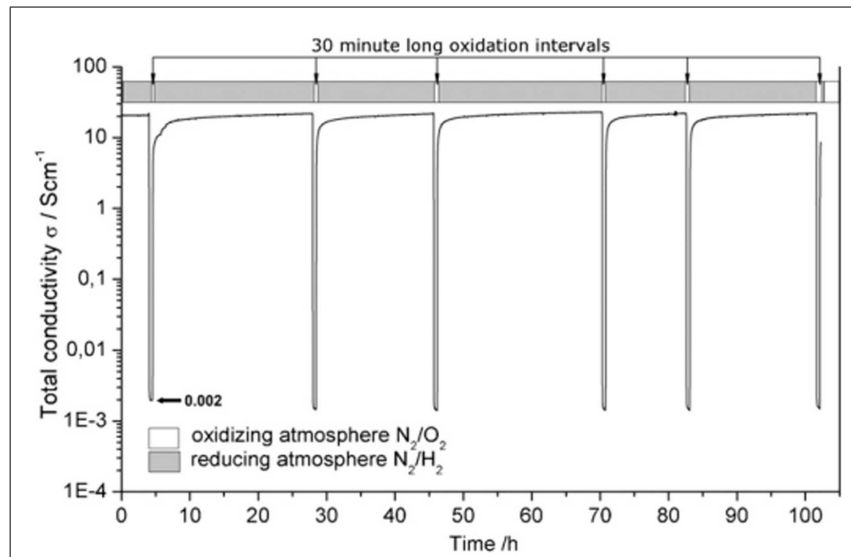

FIGURE 6 | Isothermal redox cycling at $980^{\circ} \mathrm{C}$ of air sintered

$\mathbf{L a}_{0.2} \mathbf{S r}_{0.704} \mathrm{TiO}_{3}$. Before the measurement, the reduction was lasting $24 \mathrm{~h}$ at $980^{\circ} \mathrm{C}$. Note that each $30 \mathrm{~min}$-long oxidation step has led to a complete loss of conductivity $\left(0.002 \mathrm{~S} \mathrm{~cm}^{-1}\right)$. The nitrogen flux with $250 \mathrm{ml} \mathrm{min}^{-1}$ was applied for $1 \mathrm{~min}$ before each oxidation and reduction cycle (Burnat et al., 2012). Reprinted with permission from Elsevier. different $\mathrm{P}_{\mathrm{O}_{2}}$, the conductivity of dense $\mathrm{Nb}$-doped $\mathrm{SrTiO}_{3}$ was found almost independent of the oxygen partial pressure at 500 $800^{\circ} \mathrm{C}$ (Hashimoto et al., 2007). Similar tolerance to oxidation was also reported for dense $\left(\mathrm{La}_{0.3} \mathrm{Sr}_{0.7}\right)_{0.93} \mathrm{TiO}_{3}$ sintered in reducing atmosphere by Li et al. (2010). The reason for such different conductivity change on oxidation is not clear, but it may be ascribed to the difference in the samples, such as composition, phase purity, pretreating history, and density.

Another criterion for redox-stable electrode materials is that their thermal expansion behavior must match electrolyte materials. The thermal expansion coefficients (TECs) for $\mathrm{SrTiO}_{3}-$ based materials in reducing atmospheres were reported to be $11.8 \times 10^{-6} \mathrm{~K}^{-1}$ for $\mathrm{Sr}_{0.7} \mathrm{La}_{0.3} \mathrm{TiO}_{3}\left(25-1000^{\circ} \mathrm{C}\right.$ ) (Hashimoto et al., 2006), $12.4 \times 10^{-6} \mathrm{~K}^{-1}$ for $\mathrm{Sr}_{0.93} \mathrm{Y}_{0.07} \mathrm{TiO}_{3}\left(30-800^{\circ} \mathrm{C}\right)$ ( $\mathrm{Fu}$ and Tietz, 2008), and $12.1 \times 10^{-6} \mathrm{~K}^{-1}$ for $\mathrm{Sr}_{0.94} \mathrm{Ti}_{0.9} \mathrm{Nb}_{0.1} \mathrm{O}_{3}$ (100$920^{\circ} \mathrm{C}$ ) (Blennow et al., 2008) which are close to those for the typical electrolyte materials (Kharton et al., 2004). The linear expansion of these materials was also studied in redox cycling. The chemical expansion on oxidation for $\mathrm{Sr}_{0.7} \mathrm{La}_{0.3} \mathrm{TiO}_{3}$ was about $\mathrm{dL} / L_{0}=0.51 \%$ at $1000^{\circ} \mathrm{C}$ while a reversible value of $0.14 \%$ was reported for $\mathrm{Sr}_{0.93} \mathrm{Y}_{0.07} \mathrm{TiO}_{3}$ at $830^{\circ} \mathrm{C}$. The values could be further lowered by forming ceramic composite with electrolyte materials (Kharton et al., 2004). As shown in Figure 7 below, the $\mathrm{Sr}_{0.93} \mathrm{Y}_{0.07} \mathrm{TiO}_{3}-\mathrm{YSZ}$ composite $(65: 35 \mathrm{vol} \%)$ only exhibited about $0.045 \%$ linear dimension change upon redox cycling at $820^{\circ} \mathrm{C}$ (Fu et al., 2007). These properties indicate that the overall redox stability of the donor-doped $\mathrm{SrTiO}_{3}$ materials is very good.

Blennow et al. (2009) reported the polarization resistance of the composite electrode $\mathrm{Sr}_{0.94} \mathrm{Ti}_{0.9} \mathrm{Nb}_{0.1} \mathrm{O}_{3}-\mathrm{YSZ}$ (54:46 vol\%) measured in a symmetrical cell configuration for 19 redox cycles at $850^{\circ} \mathrm{C}$ as shown in Figure 8. One redox cycle involved exposing anode in oxidizing atmospheres for $0.5-2.5 \mathrm{~h}$ and maintaining in wet $\mathrm{H}_{2}$ for $13 \mathrm{~h}$ after switching the gas. The polarization resistance

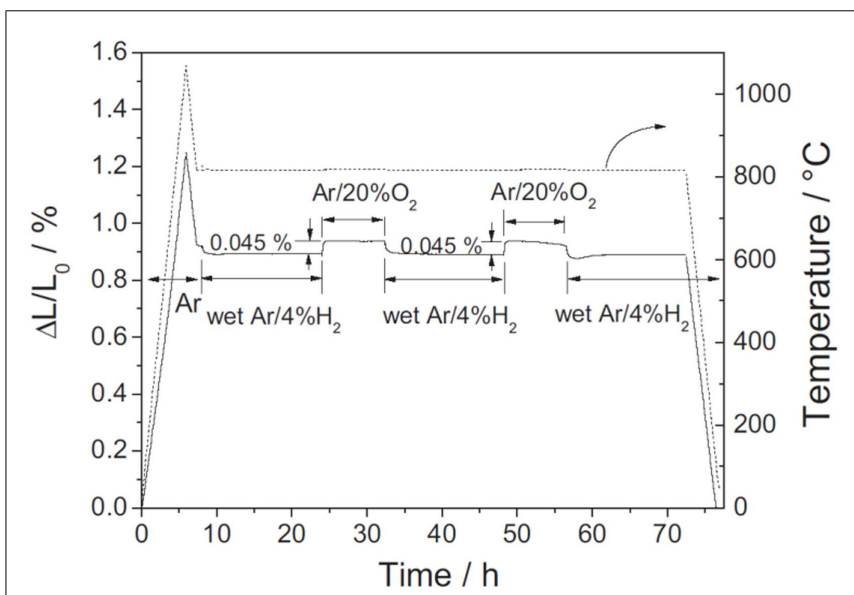

FIGURE 7 |Thermal and chemical expansion behaviors of $\mathrm{Sr}_{0.93} \mathbf{Y}_{0.07} \mathrm{TiO}_{3} / \mathrm{YSZ}(\mathbf{6 5 / 3 5} \mathrm{vol} \%$ ) ceramic composite. The sample was first heated up to $1060^{\circ} \mathrm{C}$ and cooled down to $820^{\circ} \mathrm{C}$ in $\mathrm{Ar}$, then subjected to two redox cycles between wet $\mathrm{Ar} / 4 \% \mathrm{H}_{2}$ and $\mathrm{Ar} / 20 \% \mathrm{O}_{2}$ at $820^{\circ} \mathrm{C}$, and finally cooled down to room temperature (Fu et al., 2007). Reprinted with permission from Elsevier. 


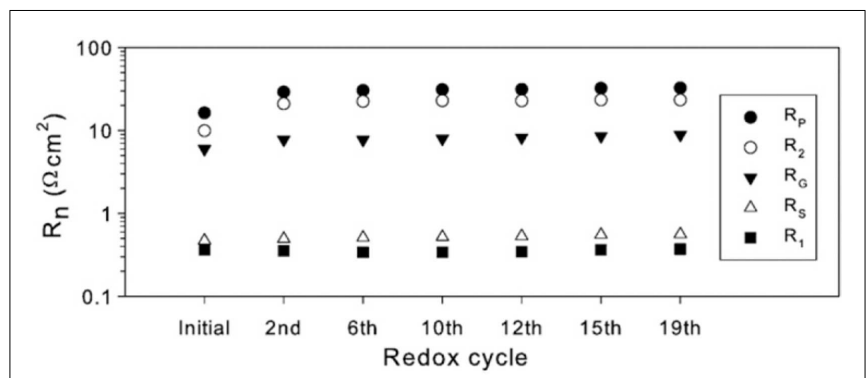

FIGURE 8 | Fitted parameters of the composite electrode $\left(\mathrm{Sr}_{0.94} \mathrm{Ti}_{0.9} \mathrm{Nb}_{0.1} \mathrm{O}_{3}-\mathrm{YSZ}\right)$ symmetrical cell as a function of redox cycles at $\mathbf{8 5 0}^{\circ} \mathbf{C}$. Each point was measured ca $13 \mathrm{~h}$ after re-reduction. $R_{\mathrm{s}}$ is the resistance determined from the high frequency offset. The polarization resistance $\left(R_{\mathrm{P}}\right)$ is the sum of $R_{1}, R_{2}$, and $R_{\mathrm{G}}$ from equivalent circuit fitting [LR $\left(Q_{1} R_{1}\right) G\left(Q_{2} R_{2}\right)$ ] (Blennow et al., 2009). Reprinted with permission from Elsevier.

increased dramatically from the initial value of $16.3-29 \Omega \mathrm{cm}^{2}$ after two redox cycles. The increased polarization resistance could be attributed to the fast oxidation and slow reduction of the titanates given that the sample was initially reduced at $980^{\circ} \mathrm{C}$ and the reduction during redox cycling was only at $850^{\circ} \mathrm{C}$. It was noted that the polarization resistance only increased by $12 \%$ after the 19th redox cycle compared with the value after the second one. Although lower polarization resistance could be expected when testing in single cells, the value for the $\mathrm{Sr}_{0.94} \mathrm{Ti}_{0.9} \mathrm{Nb}_{0.1} \mathrm{O}_{3}-\mathrm{YSZ}$ electrode is still quite large for SOFC anodes compared with Ni-YSZ cermets, implying low electrocatalytic activity for this material.

\section{DOUBLE PEROVSKITES}

Double perovskite $\mathrm{Sr}_{2} \mathrm{MgMoO}_{6}$ has been investigated as an SOFC anode candidate by Huang et al. (2006). The electronic conductivity and catalytic activity of this material rely on the $\mathrm{Mo}^{6+} / \mathrm{Mo}^{5+}$ redox couple and can be improved by replacing $\mathrm{Mg}$ with other mixed-valent cations. $\mathrm{Sr}_{2} \mathrm{FeMoO}_{6}$ exhibited much higher electrical conductivity in reducing atmosphere (about 220 versus $9 \mathrm{~S} \mathrm{~cm}^{-1}$ for $\mathrm{Sr}_{2} \mathrm{MgMoO}_{6}$ ), which is attributed to the overlap of Fe 3d, Mo 4d, and O 2p bands at Fermi level and delocalized electrons from Mo 4d band (Itoh et al., 1996; Kobayashi et al., 1998; Zhang et al., 2010). Zhang et al. measured anode performance of $\mathrm{Sr}_{2} \mathrm{FeMoO}_{6}$ on LSGM electrolyte with $\mathrm{SmBaCo}_{2} \mathrm{O}_{5+x}$ cathode, which yielded a peak power density of $584 \mathrm{~mW} \mathrm{~cm}^{-2}$ at $800^{\circ} \mathrm{C}$ in dry $\mathrm{H}_{2}$. One concern about $\mathrm{Sr}_{2} \mathrm{FeMoO}_{6}$ as an SOFC anode candidate is its narrow stable range at different oxygen partial pressures. The composition is not stable in oxidizing atmospheres at high temperatures due to that the total charge of the cations cannot be balanced by the oxygen cations in the perovskite structure. Therefore, high-temperature treatment of the anodes must be done in protective atmospheres. Additionally, even at low $\mathrm{P}_{\mathrm{O}_{2}}$, the oxide ionic conductivity of $\mathrm{Sr}_{2} \mathrm{FeMoO}_{6}$ may be low due to lack of oxygen vacancies, which limits the replenishment of $\mathrm{O}^{2-}$ ions to the anode surface and eventually causes anode surface decomposition and performance degradation (Goodenough and Huang, 2007). Therefore, improvements are needed to make this material more feasible.
Recently, Liu et al. found that the phase stability of $\mathrm{Sr}_{2} \mathrm{Fe}_{1+x} \mathrm{Mo}_{x} \mathrm{O}_{6}(0 \leq x \leq 1)$ at high oxygen partial pressures can be gradually improved when lowering the Mo content and $\mathrm{Sr}_{2} \mathrm{Fe}_{1.5} \mathrm{Mo}_{0.5} \mathrm{O}_{6}$ was found stable in both anode and cathode conditions (Liu et al., 2010a; Xiao et al., 2010). Furthermore, $\mathrm{Sr}_{2} \mathrm{Fe}_{1.5} \mathrm{Mo}_{0.5} \mathrm{O}_{6}$ exhibited good chemical compatibility with LSGM, SDC, and BZCY electrolyte materials up to $1400^{\circ} \mathrm{C}$. Its electrical conductivity at $800^{\circ} \mathrm{C}$ was measured to be about $20 \mathrm{~S} \mathrm{~cm}^{-1}$ in air and $13 \mathrm{~S} \mathrm{~cm}^{-1}$ in wet $\mathrm{H}_{2}$, indicating potential applications as both cathodes and anodes for SOFCs (Xiao et al., 2012a,b).

By lowering the Mo content of $\mathrm{Sr}_{2} \mathrm{Fe}_{1+x} \mathrm{Mo}_{x} \mathrm{O}_{6}(0 \leq x \leq 1)$, some intrinsic oxygen vacancies were also introduced into the materials. According to neutron powder diffraction refinement results, the non-stoichiometry number $\delta$ was $0.10(2)$ for the assynthesized $\mathrm{Sr}_{2} \mathrm{Fe}_{1.5} \mathrm{Mo}_{0.5} \mathrm{O}_{6-\delta}$, revealing the presence of oxygen vacancies (Muñoz-García et al., 2011). Similar result was predicted by Muñoz-García et al. with DFT + U theory (Mun oz-García et al., 2012; Muñoz-García et al., 2013). Based on first principle calculations, they found oxygen vacancies preferentially formed along $\mathrm{Fe}-\mathrm{O}-\mathrm{Fe}$ bonds rather than along $\mathrm{Mo}-\mathrm{O}-\mathrm{Fe}$ and $\mathrm{Mo}-\mathrm{O}-$ Mo bonds, and $\mathrm{Fe}-\mathrm{O}$ bond in $\mathrm{Sr}_{2} \mathrm{Fe}_{1.5} \mathrm{Mo}_{0.5} \mathrm{O}_{6}$ was relatively weak, indicating that high oxide ionic conductivity can be expected for this material. By fabricating a thin layer of LSGM electrolyte on the sample as electronic blocking layer, the oxide ionic conductivity of $\mathrm{Sr}_{2} \mathrm{Fe}_{1.5} \mathrm{Mo}_{0.5} \mathrm{O}_{6}$ was measured by Xiao et al. (2011a). The value reached $0.13 \mathrm{~S} \mathrm{~cm}^{-1}$ at $800^{\circ} \mathrm{C}$ in air, which is comparable to those for $\mathrm{SrCoO}_{3}$-based cathode materials. The chemical diffusion coefficient and surface exchange constant were also measured for $\mathrm{Sr}_{2} \mathrm{Fe}_{1.5} \mathrm{Mo}_{0.5} \mathrm{O}_{6}$, which are comparable to those of the state-of-art cathode materials. Zhang et al. found that its surface exchange kinetics can be further enhanced by surface modification with ceria-based materials. The polarization resistance was $0.076 \Omega \mathrm{cm}^{2}$ and the exchange current density was $0.186 \mathrm{~A} \mathrm{~cm}^{-2}$ at $800^{\circ} \mathrm{C}$ measured on LSGM electrolytes, showing good cathode activity of $\mathrm{Sr}_{2} \mathrm{Fe}_{1.5} \mathrm{Mo}_{0.5} \mathrm{O}_{6}$.

Liu et al. tested symmetrical fuel cells with $\mathrm{Sr}_{2} \mathrm{Fe}_{1.5} \mathrm{Mo}_{0.5} \mathrm{O}_{6}$ as both anode and cathode on LSGM electrolyte (Liu et al., 2010a, 2011). The peak power density reached above $500 \mathrm{~mW} \mathrm{~cm}^{-2}$ at $800^{\circ} \mathrm{C}$ with $\mathrm{H}_{2}$ as the fuel, which is much higher than those symmetrical fuel cells with $\mathrm{LaCrO}_{3}$-based electrode materials. As shown in Figure 10, the symmetrical cells exhibited good redox stability that the peak power density remained stable after five redox cycles at $800^{\circ} \mathrm{C}$. This feature allows the anode and cathode of symmetrical fuel cells with $\mathrm{Sr}_{2} \mathrm{Fe}_{1.5} \mathrm{Mo}_{0.5} \mathrm{O}_{6}$ electrodes to function reversely by switching the gases, making it possible to in situ regenerate the cell performance from the contaminated anode. The feasibility of regenerating cell performance using $\mathrm{Sr}_{2} \mathrm{Fe}_{1.5} \mathrm{Mo}_{0.5} \mathrm{O}_{6}$ anode upon redox cycling was demonstrated by exposing the anode in air at $800^{\circ} \mathrm{C}$ after operating in sulfur or hydrocarbon-containing fuels. As shown in Figure 9, the peak power density of the symmetrical cells was efficiently recovered after redox cycling. Due to the excellent stability and activity of $\mathrm{Sr}_{2} \mathrm{Fe}_{1.5} \mathrm{Mo}_{0.5} \mathrm{O}_{6}$, the symmetrical cell was also demonstrated as an efficient solid oxide electrolysis cell by Liu et al. (2010b). The cell was operated at $1.2 \mathrm{~V}$ at $850^{\circ} \mathrm{C}$ under highly humidified condition for about $100 \mathrm{~h}$. Only slight performance drop was observed in 


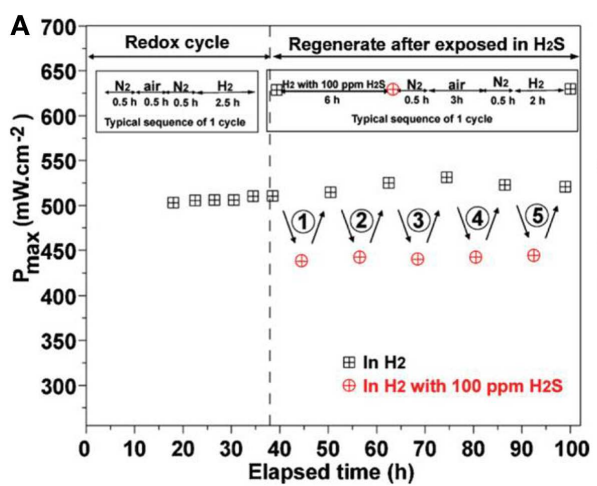

FIGURE 9 | Stability of symmetrical cells with $\mathrm{Sr}_{2} \mathrm{Fe}_{1.5} \mathrm{Mo}_{0.5} \mathrm{O}_{6}$ electrodes at $800^{\circ} \mathrm{C}$ versus the time of stream (A). In the first five cycles which are redox cycle test, the anode gas was switched between air and $\mathrm{H}_{2}$. In the last five cycle tests, the anode gas was switched between $\mathrm{H}_{2}$ and $\mathrm{H}_{2}$ with

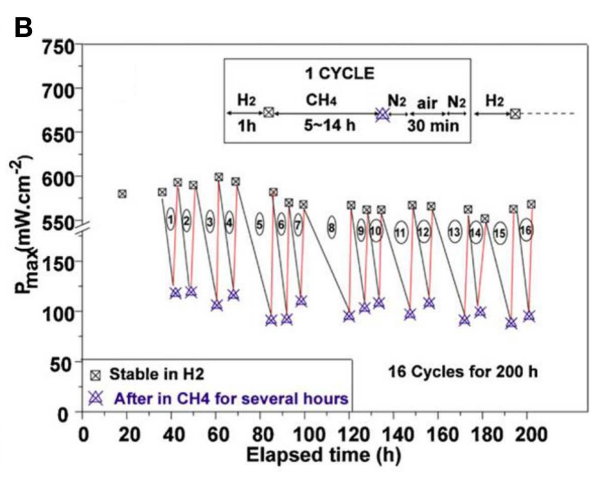

$100 \mathrm{ppm} \mathrm{H}_{2} \mathrm{~S}$. The maximum power density was recorded after each cycle, (B) the maximum power density of the cell when the anode gas was switched between $\mathrm{H}_{2}$, air, and $\mathrm{CH}_{4}$ for 16 cycles (Liu et al., 2011). Reprinted with permission from Elsevier. the initial $10 \mathrm{~h}$ test and the current became stable in the following 90 h operation.

$\mathrm{Sr}_{2} \mathrm{CoMoO}_{6}$ and $\mathrm{Sr}_{2} \mathrm{NiMoO}_{6}$ were also studied as SOFC anode materials and they showed remarkably high power density in $\mathrm{H}_{2}$ and $\mathrm{CH}_{4}$ (Huang et al., 2009; Wei et al., 2012). Similar to $\mathrm{Sr}_{2} \mathrm{MgMoO}_{6}$ and $\mathrm{Sr}_{2} \mathrm{FeMoO}_{6}$, high cation charge in these materials makes the phase stability questionable and the oxygen ionic conductivity potentially low at high oxygen partial pressures. Wei et al. (2012) lowered Mo content up to $20 \%$ in $\mathrm{Sr}_{2} \mathrm{CoMoO}_{6}$ and evaluated the materials as electrode candidates for symmetrical fuel cells. It is interesting that these $\mathrm{Sr}_{2} \mathrm{Co}_{1+x} \mathrm{Mo}_{1-x} \mathrm{O}_{6}(x=0.1$, $0.15,0.2)$ materials exhibited much lower TEC than other Cobased perovskites $\left(6-15 \times 10^{-6}\right.$ versus $\left.20-30 \times 10^{-6} \mathrm{~K}^{-1}\right)$. Symmetrical cells with $\mathrm{Sr}_{2} \mathrm{Co}_{1.15} \mathrm{Mo}_{0.85} \mathrm{O}_{6}$ as both anode and cathode exhibited a peak power density of $460 \mathrm{~mW} \mathrm{~cm}^{-2}$ at $800^{\circ} \mathrm{C}$, indicating its potential applications as redox stable electrodes.

\section{CERAMIC ANODES WITH PROMOTED CATALYTIC ACTIVITY}

Ceramic anode materials may exhibit better stability than conventional Ni-based cermet materials but their overall cell performance is still relatively low. The ceramic anode performance is limited by the electrical conductivity and catalytic activity of the materials. In some cases, the cell performance can be improved dramatically by introducing a small amount of precious metal catalysts, indicating the catalytic activity may be a dominant restraint (Kim et al., 2008; Gross et al., 2009; Zhu et al., 2009; Bi and Zhu, 2011; Smith and Gross, 2011; Xiao and Chen, 2011; Xiao et al., 2012c, 2014).

One strategy for promoting anode reactions on ceramic anode materials is to increase the number of reaction sites. Infiltration methods can be applied to extend three phase boundaries by forming nano-sized ceramic anode phases on porous electrolyte framework (Zhang and Xia, 2010; Zhang et al., 2013). As aforementioned, this method can mitigate the expansion mismatch between ceramic materials and electrolytes, potentially improving redox stability of the ceramic anodes. Fuel oxidation on ceramic materials may also be facilitated by enhancement of their oxide ionic conductivity (Fu et al., 2006; Ruiz-Morales et al., 2006b; Canales-Vázquez et al., 2007; Li et al., 2008a,b, 2009, 2010). This has been quite effective for donor-doped $\mathrm{SrTiO}_{3}$ and may also promote equilibration of $\mathrm{SrTiO}_{3}$ materials under different oxygen partial pressures (Neagu and Irvine, 2011; Suthirakun et al., 2011, 2012, 2014; Xiao et al., 2011b, 2013). Moreover, some catalysts can be directly introduced to the ceramic anodes for improving the overall anode performance. Additionally, because of the mixed conducting nature of the ceramic materials, the catalyst particles can be highly dispersed and stabilized by the ceramic phase without compromising stability (Zhu et al., 2009; Xiao and Chen, 2011; Xiao et al., 2012c).

Ma et al. (2010) reported high performance and redox stable planar single cells with dimensions of $50 \mathrm{~mm} \times 50 \mathrm{~mm}$. The cells were fabricated on a $\mathrm{Sr}_{0.895} \mathrm{Y}_{0.07} \mathrm{TiO}_{3}$ anode support and a $\left(\mathrm{Sr}_{0.89} \mathrm{Y}_{0.07}\right)_{0.91} \mathrm{TiO}_{2.91}-\mathrm{YSZ}(2: 1$ in volume) anode active layer, both infiltrated with $3 \mathrm{wt} \% \mathrm{NiO}$. A power density of $0.85 \mathrm{~W} \mathrm{~cm}^{-2}$ was achieved for the cells at $0.7 \mathrm{~V}$ at $800^{\circ} \mathrm{C}$ with $\mathrm{H}_{2}$ as the fuel. As shown in Figure 10, at $700^{\circ} \mathrm{C}$ the cells were subject to redox cycling by exposing the anode in $\mathrm{H}_{2}$ for $10 \mathrm{~min}$ and in air for another $10 \mathrm{~min}$ in a typical cycle for 200 cycles. The OCV only decreased by $1.3 \%$ and the performance of the cell decreased by $35 \%$. It was noted that cell performance almost reached stability after 100 cycles. The degradation was attributed to the slow redox kinetics of $\mathrm{Sr}_{0.895} \mathrm{Y}_{0.07} \mathrm{TiO}_{3}$ that the electrical conductivity cannot fully recover in such a short time in $\mathrm{H}_{2}$. By prolonging the reducing time to $2 \mathrm{~h}$, no evident degradation was observed for 50 redox cycles at $800^{\circ} \mathrm{C}$. The good redox stability of the cells in such scale shows very promising prospect for commercial application.

Although ceramic anodes with infiltrated catalysts exhibit promising stability and high performance, alternative approaches to obtain such catalysts modified ceramic anodes are needed due to the limitations of the infiltration method mentioned previously. Recently, in situ formation of metal catalysts on ceramic materials has been considered as an attractive way. When multivalent transition metals were introduced to the $\mathrm{B}$ site of $\mathrm{LaCrO}_{3}-$ based materials to improve their catalytic activity, Ni-doping was found more effective (Sfeir et al., 2001). Such catalytic improvement was found to arise from Ni precipitation in fuel conditions (Sauvet and Irvine, 2004). Madsen et al. (2007) observed Ru nano 


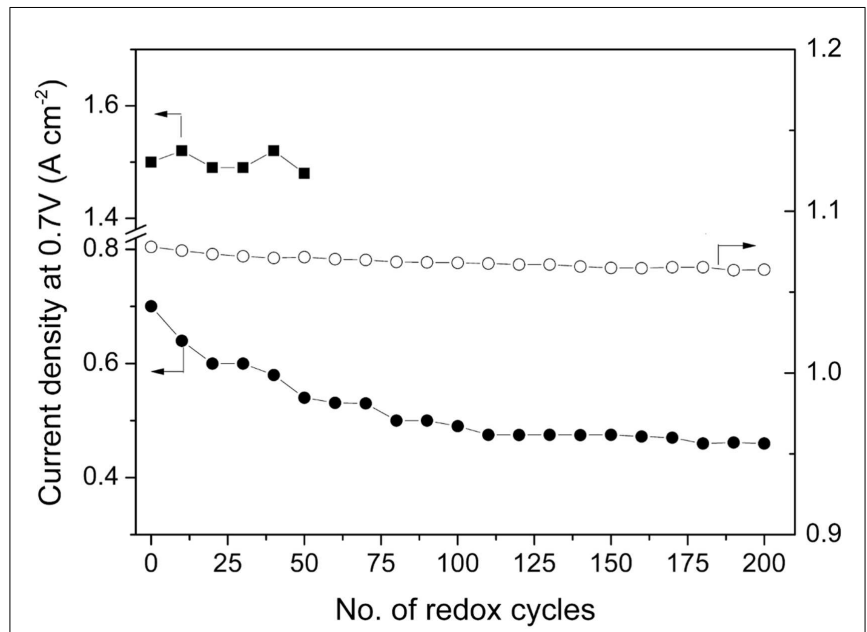

FIGURE 10 | OCV(open circles) and current density at $0.7 \mathrm{~V}$ (closed circles) as a function of the number of redox cycles (10 $\mathrm{min}$ in $\mathrm{H}_{2}$ and $10 \mathrm{~min}$ in air) at $750^{\circ} \mathrm{C}$ as well as current density at $0.7 \mathrm{~V}$ (closed squares) as a function of the number of redox cycles at $800^{\circ} \mathrm{C}$ applying $\mathbf{2} \mathbf{h}$ in $\mathbf{H}_{2}$ and $\mathbf{1 0}$ min in air (Ma et al., 2010). Reprinted with permission from Elsevier.

particles $\left(\leq 5 \mathrm{~nm}\right.$ ) formed on $\mathrm{La}_{0.8} \mathrm{Sr}_{0.2} \mathrm{Cr}_{0.82} \mathrm{Ru}_{0.18} \mathrm{O}_{3}$ surfaces after exposure to hydrogen at $800^{\circ} \mathrm{C}$. Over $50 \mathrm{~h}$ initial reduction, the formed catalysts improved peak power density of the cell from 200 to $400 \mathrm{~mW} \mathrm{~cm}^{-2}$. Similar observation was reported by Kobsiriphat et al. (2010) in $\mathrm{La}_{0.8} \mathrm{Sr}_{0.2} \mathrm{Cr}_{1-x} \mathrm{Ni}_{x} \mathrm{O}_{3}$. Larger $\mathrm{Ni}$ particles $(>10 \mathrm{~nm})$ were found extracted from the material upon reduction and agglomeration of the catalyst particles was also found to cause performance degradation over $300 \mathrm{~h}$ operation. In the similar material system, Bierschenk found that such performance degradation for Pd-doped anode materials can be regenerated upon redox cycling and the process of metal particle precipitation was reversible (Bierschenk et al., 2011). Another material $\mathrm{NbTi}_{0.5} \mathrm{M}_{0.5} \mathrm{O}_{4}$ which can generate metal particles after reduction was reported by Boulfrad et al. (2011) and Li et al. (2013). Compared with the infiltration approach, such method for generating metal modified ceramic anode is much simpler and the distribution of catalyst particles may be more homogeneous. Considering the possible interaction between these nano-sized particles and mixed ionic and electronic conducting substrates as well as reversible generation process, enhanced performance and good redox stability of these materials can be expected.

Yang et al. (2012) found that nano-sized Co-Fe alloy particles supported on a ceramic matrix can be achieved by exposing $\mathrm{Pr}_{0.4} \mathrm{Sr}_{0.6} \mathrm{Co}_{0.2} \mathrm{Fe}_{0.7} \mathrm{Nb}_{0.1} \mathrm{O}_{3}$ to a reducing environment at $900^{\circ} \mathrm{C}$ and such phase transition can be reversed by treating the composite in air at the same temperature as shown in Figure 11. When the material was applied in LSGM electrolyte-supported cells as both electrodes, the anode side turned into a composite electrode with nano-sized Co-Fe alloy particles supported on a RuddlesdenPopper phase upon in situ reduction. The cell achieved a maximum power density of $0.96 \mathrm{~W} \mathrm{~cm}^{-2}$ at $850^{\circ} \mathrm{C}$ in $\mathrm{H}_{2}$ and the values were still 0.92 and $0.89 \mathrm{~W} \mathrm{~cm}^{-2}$ at $850^{\circ} \mathrm{C}$ in $\mathrm{H}_{2}$ containing 50 and $100 \mathrm{ppm}_{2} \mathrm{~S}$, respectively. Remarkably, the cell also showed

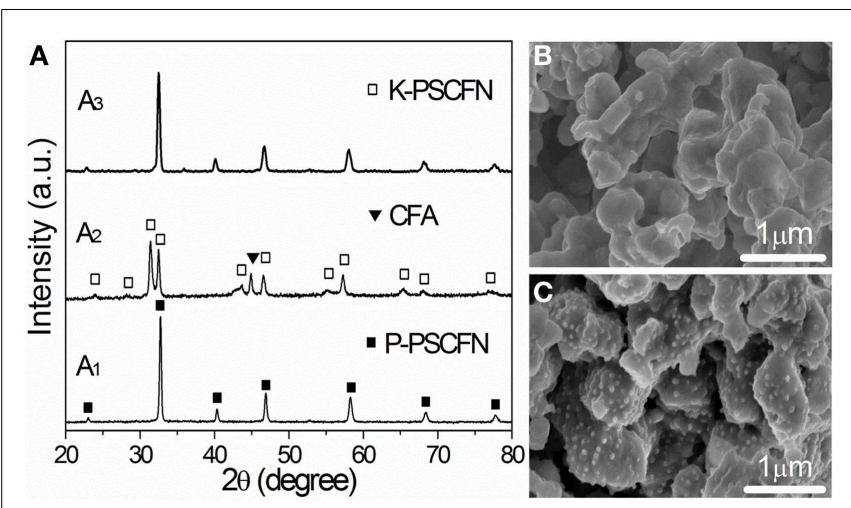

FIGURE 11 | (A) X-ray diffraction (XRD) patterns of (A1) $R \mathrm{Pr}_{0.4} \mathrm{Sr}_{0.6}$ $\mathrm{Co}_{0.2} \mathrm{Fe}_{0.7} \mathrm{Nb}_{0.1} \mathrm{O}_{3}$ sintered at $1050^{\circ} \mathrm{C}$ in air; (A2) $\mathrm{Pr}_{0.4} \mathrm{Sr}_{0.6} \mathrm{Co}_{0.2} \mathrm{Fe}_{0.7} \mathrm{Nb}_{0.1} \mathrm{O}_{3}$ annealed in $5 \% \mathrm{H}_{2}-95 \% \mathrm{~N}_{2}$ at $900^{\circ} \mathrm{C}$; and (A3) $\mathrm{Pr}_{0.4} \mathrm{Sr}_{0.6} \mathrm{Co}_{0.2} \mathrm{Fe}_{0.7} \mathrm{Nb}_{0.1} \mathrm{O}_{3}$ re-oxidized in air at $900^{\circ} \mathrm{C}$; (B,C) SEM images of $\mathrm{Pr}_{0.4} \mathrm{Sr}_{0.6} \mathrm{Co}_{0.2} \mathrm{Fe}_{0.7}$ $\mathrm{Nb}_{0.1} \mathrm{O}_{3}$ before and after being reduced in $\mathrm{H}_{2}$ at $900^{\circ} \mathrm{C}$ (Yang et al., 2012). Reprinted with permission from John Wiley and Sons.

relatively high maximum power density of $0.6 \mathrm{~W} \mathrm{~cm}^{-2}$ in $\mathrm{CH}_{4}$ and $0.94 \mathrm{~W} \mathrm{~cm}^{-2}$ in $\mathrm{C}_{3} \mathrm{H}_{8}$ at $850^{\circ} \mathrm{C}$. In contrast to the low performance of the cell with only the Ruddlesden-Popper phase as the anode, the dramatically improved performance was attributed to the alloy catalysts generated during reduction. Benefiting from formation of alloy and good stability of the ceramic substrates, the cell performance was quite stable in both $\mathrm{H}_{2} \mathrm{~S}$-containing fuels and hydrocarbon fuels for hundreds of hours. The maximum power density remained stable during a total of 26 cyclic testing, indicating excellent redox-reversibility of the anode material.

Recently, a strategy to manipulate perovskite ceramic materials to precipitate catalytic particles by introducing A-site deficiency was demonstrated in $\mathrm{La}(\mathrm{Sr}) \mathrm{TiO}_{3}$-based materials (Figure 12) (Neagu et al., 2013) and Sr-Fe-Mo-O-based materials (Xiao et al., 2014) possibly applicable to other material systems. Xiao et al. investigated the anode performance of $\mathrm{Sr}_{1.9} \mathrm{Fe}_{1.4} \mathrm{Ni}_{0.1} \mathrm{Mo}_{0.5} \mathrm{O}_{6}$ SDC on LSGM electrolyte with LSCF as the cathode. Besides the improvement in cell performance, good redox stability of the composite anode was also demonstrated. As shown in Figure 13, the cell performance was not sensitive to the exposing time in air in contrast to that reported for the cells with $\mathrm{SrTiO}_{3}$-based materials (Ma et al., 2010) suggesting that the ceramic phase may have an important role in determining the stability of the modified ceramic anode materials. The impacts of the catalysts precipitation during reduction on properties of the ceramic substrate phase are not clear and may require further systematic studies in the future.

\section{CONCLUSION}

Aiming at implementation of SOFCs under practical conditions, the instability issue for conventional Ni-cermet-based anodes in redox cycling has been intensively studied. The cell performance degradation can be attributed to the dramatically volume change of the Ni-phase, specifically during oxidation at high temperatures. Recent research work has demonstrated that the redox instability issues for Ni-cermet anode can be effectively mitigated by carefully 


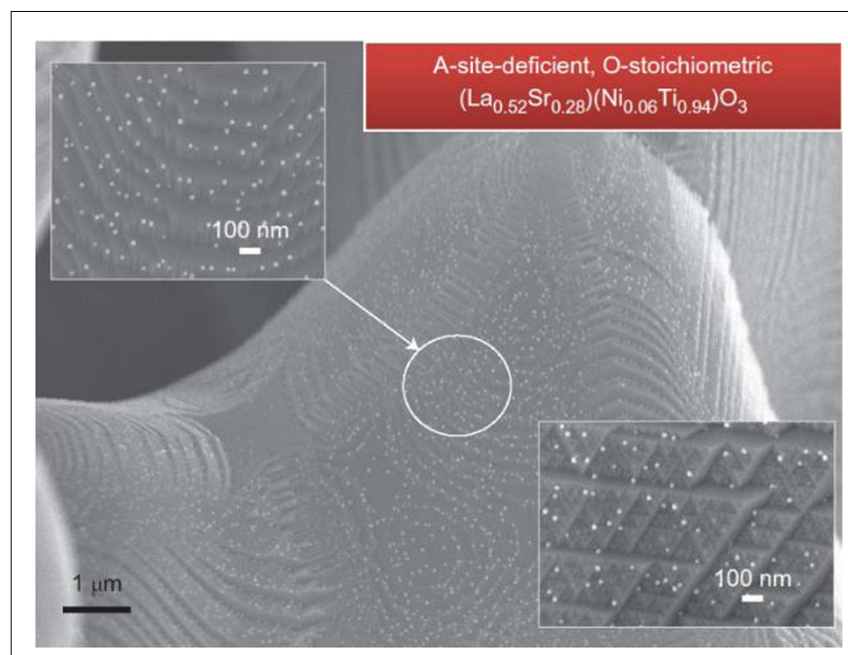

FIGURE 12 | Ex-solutions from the initially A-site-deficient, O-stoichiometric $\mathrm{La}_{0.52} \mathrm{Sr}_{0.28} \mathrm{Ni}_{0.06} \mathrm{Ti}_{0.94} \mathrm{O}_{3}$ after reduction at $930^{\circ} \mathrm{C}(20 \mathrm{~h})$ in $\mathbf{5 \%} \mathbf{H}_{2} / \mathbf{A r}$ (Neagu et al., 2013). Reprinted with permission from Nature Publishing Group.

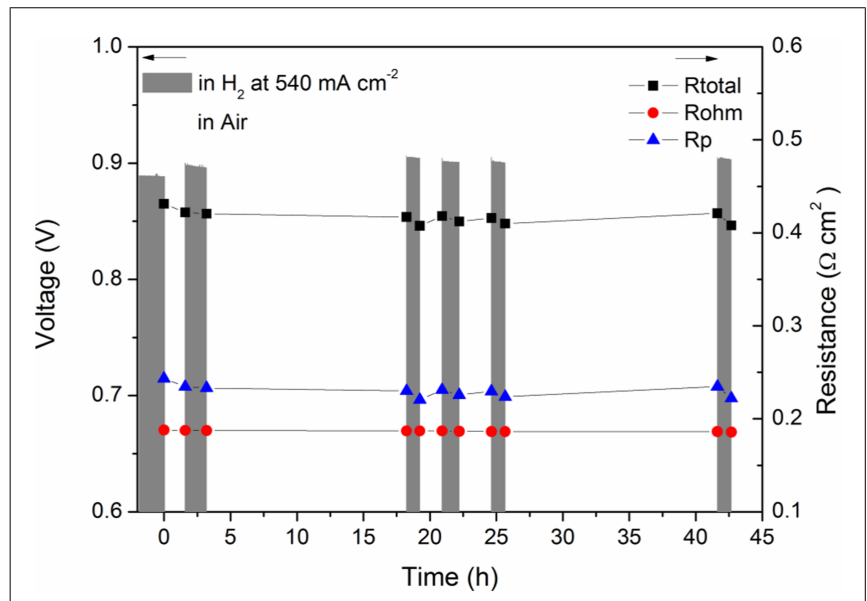

FIGURE 13 | Cell voltage and resistance of $\mathrm{Sr}_{1.9} \mathrm{Fe}_{1.4} \mathrm{Ni}_{0.1} \mathrm{Mo}_{0.5} \mathrm{O}_{6-\delta}-\mathrm{SDC}$ anode versus time during redox cycling (Xiao et al., 2014). Reprinted with permission of The Electrochemical Society.

tailoring the microstructure of the composites, including decreasing the initial Ni particle size, enhancing mechanical strength of the ceramic frame, and increasing anode porosity. By using infiltration method, the electrical conductivity and electrochemical performance of Ni-cermet anodes were preserved after a few redox cycles. Meanwhile, developing novel ceramic anode materials has been considered as an alternative strategy to mitigate redox instability limitations for $\mathrm{Ni}$-cermet anode and has already drawn great research interests. Several potential ceramic anode candidates have been demonstrated. With judicious material design, remarkable single cell performance and promising stability in redox cycling have been demonstrated for some ceramic-based materials as SOFC anodes. These findings indicate that it is feasible to solve the redox instability issues of SOFC anodes by exploring new anode materials and optimizing anode microstructures.

\section{ACKNOWLEDGMENTS}

This work was supported by the U.S. National Science Foundation (DMR-1210792) and as part of the HeteroFoaM Center, an Energy Frontier Research Center funded by the U.S. Department of Energy, Office of Science, Basic Energy Sciences under Award \# DESC0001061.

\section{REFERENCES}

Atkinson, A. (1987). Growth of $\mathrm{NiO}$ and $\mathrm{SiO}_{2}$ thin films. Philos. Mag. (Abingdon) 55, 637-650. doi:10.1080/13642818708218370

Bastidas, D. M., Tao, S. W., and Irvine, J. T. S. (2006). A symmetrical solid oxide fuel cell demonstrating redox stable perovskite electrodes. J. Mater. Chem. 16, 1603-1605. doi:10.1039/B600532B

Bi, Z. H., and Zhu, J. H. (2011). Effect of current collecting materials on the performance of the double-perovskite $\mathrm{Sr}_{2} \mathrm{MgMoO}_{6}$-delta anode. J. Electrochem. Soc. 158, B605-B613. doi:10.1149/1.3569754

Bierschenk, D. M., Potter-Nelson, E., Hoel, C., Liao, Y. G., Marks, L., Poeppelmeier, K. R., et al. (2011). Pd-substituted ( $\mathrm{La}, \mathrm{Sr}) \mathrm{CrO}_{3}$-delta-Ce ${ }_{0.9} \mathrm{Gd}_{0.1} \mathrm{O}_{2}$-delta solid oxide fuel cell anodes exhibiting regenerative behavior. J. Power Sources 196, 3089-3094. doi:10.1016/j.jpowsour.2010.12.050

Blennow, P., Hagen, A., Hansen, K. K., Wallenberg, L. R., and Mogensen, M. (2008). Defect and electrical transport properties of $\mathrm{Nb}$-doped $\mathrm{SrTiO}_{3}$. Solid State Ionics 179, 2047-2058. doi:10.1016/j.ssi.2008.06.023

Blennow, P., Hansen, K. K., Wallenberg, L. R., and Mogensen, M. (2009). Electrochemical characterization and redox behavior of $\mathrm{Nb}$-doped $\mathrm{SrTiO}_{3}$. Solid State Ionics 180, 63-70. doi:10.1016/j.ssi.2008.10.011

Boulfrad, S., Cassidy, M., and Irvine, J. T. S. (2011). $\mathrm{NbTi}_{0.5} \mathrm{Ni}_{0.5} \mathrm{O}_{4}$ as anode compound material for SOFCs. Solid State Ionics 197, 37-41. doi:10.1016/j.ssi.2011. 05.007

Burnat, D., Heel, A., Holzer, L., Kata, D., Lis, J., and Graule, T. (2012). Synthesis and performance of A-site deficient lanthanum-doped strontium titanate by nanoparticle based spray pyrolysis. J. Power Sources 201, 26-36. doi:10.1016/j. jpowsour.2011.10.088

Busawon, A., Sarantaridis, D., and Atkinson, A. (2008). Ni infiltration as a possible solution to the redox problem of SOFC anodes. Electrochem. Solid State Lett. 11, B186-B189. doi:10.1149/1.2959078

Buyukaksoy, A., Petrovsky, V., and Dogan, F. (2012). Redox stable solid oxide fuel cells with Ni-YSZ cermet anodes prepared by polymeric precursor infiltration. J. Electrochem. Soc. 159, B232-B234. doi:10.1149/2.082202jes

Canales-Vázquez, J., Ruiz-Morales, J. C., Marrero-López, D., Peña-Martínez, J., Núñez, P., and Gómez-Romero, P. (2007). Fe-substituted (La, Sr) $\mathrm{TiO}_{3}$ as potential electrodes for symmetrical fuel cells (SFCs). J. Power Sources 171, 552-557. doi:10.1016/j.jpowsour.2007.05.094

Cassidy, M., Lindsay, G., and Kendall, K. (1996). The reduction of nickel-zirconia cermet anodes and the effects on supported thin electrolytes. J. Power Sources 61, 189-192. doi:10.1016/S0378-7753(96)02359-2

de Souza, S., Visco, S. J., and De Jonghe, L. C. (1997). Reduced temperature solid oxide fuel cell based on YSZ thin film electrolyte. J. Electrochem. Soc. 144, L35-L37. doi:10.1149/1.1837484

Ettler, M., Timmermann, H., Malzbender, J., Weber, A., and Menzler, N. H. (2010). Durability of Ni anodes during reoxidation cycles. J. Power Sources 195, 5452-5467. doi:10.1016/j.jpowsour.2010.03.049

Faes, A., Hessler-Wyser, A., and Zryd, A. (2012). A review of Redox cycling of solid oxide fuel cells anode. Membranes 2, 585-664. doi:10.3390/ membranes 2030585

Fouquet, D., Muller, A. C., Weber, A., and Ivers-Tiffee, E. (2003). Kinetics of oxidation and reduction of Ni/YSZ cermets. Ionics (Kiel) 9, 103-108. doi:10.1007/ Bf02376545

Fu, Q. X., and Tietz, F. (2008). Ceramic-based anode materials for improved redox cycling of solid oxide fuel cells. Fuel Cells 8, 283-293. doi:10.1002/fuce.200800018

Fu, Q. X., Tietz, F., Sebold, D., Tao, S. W., and Irvine, J. T. S. (2007). An efficient ceramic-based anode for solid oxide fuel cells. J. Power Sources 171, 663-669. doi:10.1016/j.jpowsour.2007.06.159 
Fu, Q. X., Tietz, F., and Stover, D. (2006). $\mathrm{La}_{0.4} \mathrm{Sr}_{0.6} \mathrm{Ti}_{1-x} \mathrm{MnxO}_{3}$-delta perovskites as anode materials for solid oxide fuel cells. J. Electrochem. Soc. 153, D74-D83. doi:10.1149/1.2170585

Goodenough, J. B., and Huang, Y. H. (2007). Alternative anode materials for solid oxide fuel cells. J. Power Sources 173, 1-10. doi:10.1016/j.jpowsour.2007.08.011

Gorte, R. J., Kim, H., and Vohs, J. M. (2002). Novel SOFC anodes for the direct electrochemical oxidation of hydrocarbon. J. Power Sources 106, 10-15. doi:10.1016/S0378-7753(01)01021-7

Grahl-Madsen, L., Larsen, P. H., Bonanos, N., Engell, J., and Linderoth, S. (2006). Mechanical strength and electrical conductivity of Ni-YSZ cermets fabricated by viscous processing. J. Mater. Sci. 41, 1097-1107. doi:10.1007/s10853-005-3647-3

Gross, M. D., Carver, K. M., Deighan, M. A., Schenkel, A., Smith, B. M., and Yee, A. Z. (2009). Redox stability of $\mathrm{SrNbxTi}_{1-x} \mathrm{O}_{3}-\mathrm{YSZ}$ for use in SOFC anodes. J. Electrochem. Soc. 156, B540-B545. doi:10.1149/1.3078406

Haga, K., Adachi, S., Shiratori, Y., Itoh, K., and Sasaki, K. (2008a). Poisoning of SOFC anodes by various fuel impurities. Solid State Ionics 179, 1427-1431. doi:10.1016/j.ssi.2008.02.062

Haga, K., Shiratori, Y., Ito, K., and Sasaki, K. (2008b). Chlorine poisoning of SOFC Ni-cermet anodes. J. Electrochem. Soc. 155, B1233-B1239. doi:10.1149/ 1.2980521

Hashimoto, S., Kindermann, L., Larsen, P. H., Poulsen, F. W., and Mogensen, M. (2006). Conductivity and expansion at high temperature in $\mathrm{Sr}_{0.7} \mathrm{La}_{0.3} \mathrm{TiO}_{3}$ alpha prepared under reducing atmosphere. J. Electroceram. 16, 103-107. doi:10.1007/s10832-006-3490-1

Hashimoto, S., Poulsen, F. W., and Mogensen, M. (2007). Conductivity of $\mathrm{SMO}_{3}$ based oxides in the reducing atmosphere at high temperature. J. Alloys Compd. 439, 232-236. doi:10.1016/j.jallcom.2006.05.138

Huang, K., and Goodenough, J. B. (2009). Solid Oxide Fuel Cell Technology: Principles, Performance and Operations. Cambridge: Woodhead Publishing Ltd.

Huang, Y. H., Dass, R. I., Denyszyn, J. C., and Goodenough, J. B. (2006). Synthesis and characterization of $\mathrm{Sr}_{2} \mathrm{MgMoO}_{6}$-delta - an anode material for the solid oxide fuel cell. J. Electrochem. Soc. 153, A1266-A1272. doi:10.1149/1.2195882

Huang, Y. H., Liang, G., Croft, M., Lehtimaki, M., Karppinen, M., and Goodenought J. B. (2009). Double-perovskite anode materials $\mathrm{Sr}_{2} \mathrm{MMoO}_{6}(\mathrm{M}=\mathrm{Co}, \mathrm{Ni})$ for solid oxide fuel cells. Chem. Mater. 21, 2319-2326. doi:10.1021/Cm8033643

Hui, S., and Petric, A. (2002). Evaluation of yttrium-doped $\mathrm{SrTiO}_{3}$ as an anode for solid oxide fuel cells. J. Eur. Ceram. Soc. 22, 1673-1681. doi:10.1016/S09552219(01)00485-X

Ishihara, T., Yan, J., Shinagawa, M., and Matsumoto, H. (2006). Ni-Fe bimetallic anode as an active anode for intermediate temperature SOFC using $\mathrm{LaGaO}_{3}$ based electrolyte film. Electrochim. Acta 52, 1645-1650. doi:10.1016/j.electacta. 2006.03.103

Itoh, H., Yamamoto, T., Mori, M., Horita, T., Sakai, N., Yokokawa, H., et al. (1997). Configurational and electrical behavior of Ni-YSZ cermet with novel microstructure for solid oxide fuel cell anodes. J. Electrochem. Soc. 144, 641-646. doi: $10.1149 / 1.1837460$

Itoh, M., Ohta, I., and Inaguma, Y. (1996). Valency pair and properties of 1:1 ordered perovskite-type compounds $\mathrm{Sr}(2) \mathrm{MMoO}(6)(\mathrm{M}=\mathrm{Mn}, \mathrm{Fe}, \mathrm{Co})$. Mater. Sci. Eng $B$ Solid 41, 55-58. doi:10.1016/S0921-5107(96)01623-6

Jiang, S. P. (2008). Development of lanthanum strontium manganite perovskite cathode materials of solid oxide fuel cells: a review. J. Mater. Sci. 43, 6799-6833. doi:10.1007/s10853-008-2966-6

Kharton, V. V., Marques, F. M. B., and Atkinson, A. (2004). Transport properties of solid oxide electrolyte ceramics: a brief review. Solid State Ionics 174, 135-149. doi:10.1016/j.ssi.2004.06.015

Kim, G., Corre, G., Irvine, J. T. S., Vohs, J. M., and Gorte, R. J. (2008). Engineering composite oxide SOFC anodes for efficient oxidation of methane. Electrochem. Solid State Lett. 11, B16-B19. doi:10.1149/1.2817809

Kim, H., Lu, C., Worrell, W., Vohs, J., and Gorte, R. (2002). Cu-Ni cermet anodes for direct oxidation of methane in solid-oxide fuel cells. J. Electrochem. Soc. 149, A247-A250. doi:10.1149/1.1445170

Kim, S. D., Moon, H., Hyun, S. H., Moon, J., Kim, J., and Lee, H. W. (2006) Performance and durability of Ni-coated YSZ anodes for intermediate temperature solid oxide fuel cells. Solid State Ionics. 177, 931-938. doi:10.1016/j.ssi.2006. 02.007

Klemensø, T., Appel, C., and Mogensen, M. (2006). In situ observations of microstructural changes in SOFC anodes during redox cycling. Electrochem. Solid State Lett. 9, A403-A407. doi:10.1149/1.2214303
Klemensø, T., Chung, C., Larsen, P. H., and Mogensen, M. (2005). The mechanism behind redox instability of anodes in high-temperature SOFCs. J. Electrochem. Soc. 152, A2186-A2192. doi:10.1149/1.2048228

Klemenso, T., and Mogensen, M. (2007). Ni-YSZ solid oxide fuel cell anode behavior upon redox cycling based on electrical characterization. J. Am. Ceram Soc. 90, 3582-3588. doi:10.1111/j.1551-2916.2007.01909.x

Kobayashi, K. L., Kimura, T., Sawada, H., Terakura, K., and Tokura, Y. (1998). Roomtemperature magnetoresistance in an oxide material with an ordered doubleperovskite structure. Nature 395, 677-680. doi:10.1038/27167

Kobsiriphat, W., Madsen, B. D., Wang, Y., Shah, M., Marks, L. D., and Barnett, S. A. (2010). Nickel- and ruthenium-doped lanthanum chromite anodes: effects of nanoscale metal precipitation on solid oxide fuel cell performance. J. Electrochem. Soc. 157, B279-B284. doi:10.1149/1.3269993

Kolodiazhnyi, T., and Petric, A. (2005). The applicability of Sr-deficient n-type $\mathrm{SrTiO}_{3}$ for SOFC anodes. J. Electroceram. 15, 5-11. doi:10.1007/s10832-0050375-7

Laurencin, J., Delette, G., Lefebvre-Joud, F., and Dupeux, M. (2008). A numerical tool to estimate SOFC mechanical degradation: case of the planar cell configuration. J. Eur. Ceram Soc. 28, 1857-1869. doi:10.1016/j.jeurceramsoc.2007.12.025

Li, S., Qin, Q., Xie, K., Wang, Y., and Wu, Y. (2013). High-performance fuel electrodes based on $\mathrm{NbTi}_{0.5} \mathrm{M}_{0.5} \mathrm{O}_{4}(\mathrm{M}=\mathrm{Ni}, \mathrm{Cu})$ with reversible exsolution of the nano-catalyst for steam electrolysis. J. Mater. Chem. A 1, 8984-8993. doi:10.1039/C3TA10404D

Li, X., Zhao, H. L., Gao, F., Chen, N., and Xu, N. S. (2008a). La and Sc co-doped $\mathrm{SrTiO}_{3}$ as novel anode materials for solid oxide fuel cells. Electrochem. Commun. 10, 1567-1570. doi:10.1016/j.elecom.2008.08.017

Li, X., Zhao, H. L., Gao, F., Zhu, Z. M., Chen, N., and Shen, W. (2008b). Synthesis and electrical properties of Co-doped $\mathrm{Y}_{0.08} \mathrm{Sr}_{0.92} \mathrm{TiO}_{3}$-delta as a potential SOFC anode. Solid State Ionics 179, 1588-1592. doi:10.1016/j.ssi.2007.12.097

Li, X., Zhao, H. L., Xu, N. S., Zhou, X., Zhany, C. J., and Chen, N. (2009). Electrical conduction behavior of $\mathrm{La}$, Co co-doped $\mathrm{SrTiO}_{3}$ perovskite as anode material for solid oxide fuel cells. Int. J. Hydrogen Energy 34, 6407-6414. doi:10.1016/j.ijhydene.2009.05.079

Li, X., Zhao, H. L., Zhou, X. O., Xu, N. S., Xie, Z. X., and Chen, N. (2010). Electrical conductivity and structural stability of La-doped $\operatorname{SrTiO}(3)$ with A-site deficiency as anode materials for solid oxide fuel cells. Int. J. Hydrogen Energy 35, 7913-7918. doi:10.1016/j.ijhydene.2010.05.043

Liu, Q., Bugaris, D. E., Xiao, G. L., Chmara, M., Ma, S. G., zur Loye, H. C., et al. (2011). $\mathrm{Sr}_{2} \mathrm{Fe}_{1.5} \mathrm{Mo}_{0.5} \mathrm{O}_{6}$-delta as a regenerative anode for solid oxide fuel cells. J. Power Sources 196, 9148-9153. doi:10.1016/j.jpowsour.2011.06.085

Liu, Q. A., Dong, X. H., Xiao, G. L., Zhao, F., and Chen, F. L. (2010a). A novel electrode material for symmetrical SOFCs. Adv. Mater. Weinheim 22, 5478-5482. doi:10.1002/adma.201001044

Liu, Q., Yang, C., Dong, X., and Chen, F. (2010b). Perovskite $\mathrm{Sr}_{2} \mathrm{Fe}_{1.5} \mathrm{Mo}_{0.5} \mathrm{O}_{6}$-delta as electrode materials for symmetrical solid oxide electrolysis cells. Int. J. Hydrogen Energy 35, 10039-10044. doi:10.1016/j.ijhydene.2010.08.016

Ma, Q. L., Tietz, F., Leonide, A., and Ivers-Tiffee, E. (2010). Anode-supported planar SOFC with high performance and redox stability. Electrochem. Commun. 12, 1326-1328. doi:10.1016/j.elecom.2010.07.011

Madsen, B. D., Kobsiriphat, W., Wang, Y., Marks, L. D., and Barnett, S. A. (2007). Nucleation of nanometer-scale electrocatalyst particles in solid oxide fuel cell anodes. J. Power Sources 166, 64-67. doi:10.1016/j.jpowsour.2006.12.080

Malzbender, J., and Steinbrech, R. W. (2007). Advanced measurement techniques to characterize thermo-mechanical aspects of solid oxide fuel cells. J. Power Sources 173, 60-67. doi:10.1016/j.jpowsour.2007.07.072

Matsuzaki, Y., and Yasuda, I. (2000). The poisoning effect of sulfur-containing impurity gas on a SOFC anode: part I. Dependence on temperature, time, and impurity concentration. Solid State Ionics 132, 261-269. doi:10.1016/S0167-2738(00) 00653-6

Monzon, H., and Laguna-Bercero, M. A. (2012). Redox-cycling studies of anodesupported microtubular solid oxide fuel cells. Int. J. Hydrogen Energy 37, 7262-7270. doi:10.1016/j.ijhydene.2011.10.026

Moos, R., and Hardtl, K. H. (1996). Electronic transport properties of Sr1-xLaxTiO ceramics. J. Appl. Phys. 80, 393-400. doi:10.1063/1.362796

Muñoz-García, A. B., Pavone, M., Ritzmann, A. M., and Carter, E. A. (2013). Oxide ion transport in $\mathrm{Sr}_{2} \mathrm{Fe}_{1.5} \mathrm{Mo}_{0.5} \mathrm{O}_{6-\delta}$, a mixed ion-electron conductor: new insights from first principles modeling. Phys. Chem. Chem. Phys. 15, 6250-6259. doi:10.1039/C3CP50995H 
Mun oz-García, A. B., Bugaris, D. E., Pavone, M., Hodges, J. P., Huq, A., Chen, F., et al. (2012). Unveiling structure-property relationships in $\mathrm{Sr}_{2} \mathrm{Fe}(1.5) \mathrm{Mo}(0.5) \mathrm{O}(6-\delta)$, an electrode material for symmetric solid oxide fuel cells. J. Am. Chem. Soc. 134, 6826-6833. doi:10.1021/ja300831k

Muñoz-García, A. B., Pavone, M., and Carter, E. A. (2011). Effect of antisite defects on the formation of oxygen vacancies in $\mathrm{Sr}_{2} \mathrm{FeMoO}_{6}$ : implications for ion and electron transport. Chem. Mater. 23, 4525-4536. doi:10.1021/cm201799c

Neagu, D., and Irvine, J. T. S. (2011). Enhancing electronic conductivity in strontium titanates through correlated A and B-site doping. Chem. Mater. 23, 1607-1617. doi:10.1021/Cm103489r

Neagu, D., Tsekouras, G., Miller, D. N., Menard, H., and Irvine, J. T. S. (2013). In situ growth of nanoparticles through control of non-stoichiometry. Nat. Chem. 5, 916-923. doi:10.1038/NCHEM.1773

Oudar, J. (1980). Sulfur adsorption and poisoning of metallic catalysts. Cat. Rev. Sci. Eng. 22, 171-195. doi:10.1080/03602458008066533

Pihlatie, M., Ramos, T., and Kaiser, A. (2009). Testing and improving the redox stability of Ni-based solid oxide fuel cells. J. Power Sources 193, 322-330. doi:10.1016/j.jpowsour.2008.11.140

Primdahl, S., Hansen, J., Grahl-Madsen, L., and Larsen, P. (2001). Sr-doped $\mathrm{LaCrO}_{3}$ anode for solid oxide fuel cells. J. Electrochem. Soc. 148, A74-A81. doi:10.1149/1.1344519

Ruiz-Morales, J. C., Canales-Vázquez, J., Peña-Martínez, J., Marrero-Lopez, D., and Nunez, P. (2006a). On the simultaneous use of $\mathrm{La}_{0.75} \mathrm{Sr}_{0.25} \mathrm{Cr}_{0.5} \mathrm{Mn}_{0.5} \mathrm{O}_{3-\delta}$ as both anode and cathode material with improved microstructure in solid oxide fuel cells. Electrochim. Acta 52, 278-284. doi:10.1016/j.electacta.2006.05.006

Ruiz-Morales, J. C., Canales-Vazquez, J., Savaniu, C., Marrero-Lopez, D., Zhou, W.Z., and Irvine, J. T. S. (2006b). Disruption of extended defects in solid oxide fuel cell anodes for methane oxidation. Nature 439, 568-571. doi:10.1038/Nature04438

Ruiz-Morales, J. C., Lincke, H., Marrero-López, D., Canales-Vázquez, J., and Núñez, P. (2007a). Lanthanum chromite materials as potential symmetrical electrodes for solid oxide fuel cells. Bol. Soc. Esp. Cerám. V. 46, 218-223. doi:10.3989/cyv.2007.v46.i4.240

Ruiz-Morales, J. C., Canales-Vázquez, J., Ballesteros-Pérez, B., Peña-Martínez, J., Marrero-López, D., Irvine, J. T., et al. (2007b). LSCM-(YSZ-CGO) composites as improved symmetrical electrodes for solid oxide fuel cells. J. Eur. Ceram Soc. 27, 4223-4227. doi:10.1016/j.jeurceramsoc.2007.02.117

Ruiz-Morales, J. C., Marrero-López, D., Canales-Vázquez, J., and Irvine, J. T. (2011). Symmetric and reversible solid oxide fuel cells. RSC Adv. 1, 1403-1414. doi:10.1039/C1RA00284H

Sarantaridis, D., and Atkinson, A. (2007). Redox cycling of Ni-based solid oxide fuel cell anodes: a review. Fuel Cells 7, 246-258. doi:10.1002/fuce.200600028

Sauvet, A., and Irvine, J. (2004). Catalytic activity for steam methane reforming and physical characterisation of $\mathrm{La}_{1-x} \mathrm{Sr}_{x} \mathrm{Cr}_{1-y} \mathrm{Ni}_{y} \mathrm{O}_{3-\delta}$. Solid State Ionics 167, 1-8. doi:10.1016/j.ssi.2003.11.021

Sfeir, J., Buffat, P. A., Möckli, P., Xanthopoulos, N., Vasquez, R., Joerg Mathieu, H., et al. (2001). Lanthanum chromite based catalysts for oxidation of methane directly on SOFC anodes. J. Catal. 202, 229-244. doi:10.1006/jcat.2001.3286

Singhal, S. (2003). High-temperature Solid Oxide Fuel Cells: Fundamentals, Design and Applications. Oxford: Elsevier.

Smith, B. H., and Gross, M. D. (2011). A highly conductive oxide anode for solid oxide fuel cells. Electrochem. Solid State Lett. 14, B1-B5. doi:10.1149/1.3505101

Sun, C., and Stimming, U. (2007). Recent anode advances in solid oxide fuel cells. J. Power Sources 171, 247-260. doi:10.1016/j.jpowsour.2007.06.086

Suthirakun, S., Ammal, S. C., Xiao, G., Chen, F., Huang, K., Zur Loye, H. C., et al. (2012). Obtaining mixed ionic/electronic conductivity in perovskite oxides in a reducing environment: a computational prediction for doped $\mathrm{SrTiO}_{3}$. Solid State Ionics 228, 37-45. doi:10.1016/issi.2012.09.013

Suthirakun, S., Ammal, S. C., Xiao, G., Chen, F., zur Loye, H. C., and Heyden, A. (2011). Density functional theory study on the electronic structure of $\mathrm{n}$ - and p-type doped $\mathrm{SrTiO}_{3}$ at anodic solid oxide fuel cell conditions. Phys. Rev. B 84, doi:10.1103/PhysRevB.84.205102

Suthirakun, S., Xiao, G., Ammal, S. C., Chen, F., zur Loye, H. C., and Heyden, A. (2014). Rational design of mixed ionic and electronic conducting perovskite oxides for solid oxide fuel cell anode materials: a case study for doped $\mathrm{SrTiO}_{3}$. J. Power Sources 245, 875-885. doi:10.1016/j.jpowsour.2013.07.040

Takeguchi, T., Kani, Y., Yano, T., Kikuchi, R., Eguchi, K., Tsujimoto, K., et al. (2002). Study on steam reforming of $\mathrm{CH}_{4}$ and $\mathrm{C}_{2}$ hydrocarbons and carbon deposition on Ni-YSZ cermets. J. Power Sources 112, 588-595. doi:10.1016/S0378-7753(02) 00471-8
Tao, S. W., and Irvine, J. T. S. (2003). A redox-stable efficient anode for solid-oxide fuel cells. Nat. Mater. 2, 320-323. doi:10.1038/nmat871

Thouless, M. D. (1991). Cracking and delamination of coatings. J. Vac. Sci. Technol. A 9, 2510-2515. doi:10.1116/1.577265

Tikekar, N. M., Armstrong, T. J., and Virkar, A. V. (2006). Reduction and reoxidation kinetics of nickel-based SOFC anodes. J. Electrochem. Soc. 153, A654-A663. doi: 10.1149/1.2167949

Tsoga, A., Naoumidis, A., and Nikolopoulos, P. (1996). Wettability and interfacial reactions in the systems $\mathrm{Ni} / \mathrm{YSZ}$ and Ni/Ti-TiO $2 / \mathrm{YSZ}$. Acta Mater. 44, 3679-3692. doi:10.1016/1359-6454(96)00019-5

Waldbillig, D., Wood, A., and Ivey, D. G. (2005). Thermal analysis of the cyclic reduction and oxidation behaviour of SOFC anodes. Solid State Ionics 176, 847-859. doi:10.1016/j.ssi.2004.12.002

Waldbillig, D., Wood, A., and Ivey, D. G. (2007). Enhancing the redox tolerance of anode-supported SOFC by microstructural modification. J. Electrochem. Soc. 154, B133-B138. doi:10.1149/1.2402116

Wei, T., Zhang, Q., Huang, Y. H., and Goodenough, J. B. (2012). Cobalt-based double-perovskite symmetrical electrodes with low thermal expansion for solid oxide fuel cells. J. Mater. Chem. 22, 225-231. doi:10.1039/C1jm14756k

Wood, A., Pastula, M., Waldbillig, D., and Ivey, D. (2006). Initial testing of solutions to redox problems with anode-supported SOFC. J. Electrochem. Soc. 153, A1929-A1934. doi:10.1149/1.2240085

Xiao, G., and Chen, F. (2011). Ni modified ceramic anodes for direct-methane solid oxide fuel cells. Electrochem. Commun. 13, 57-59. doi:10.1016/j.elecom. 2010.11.012

Xiao, G., Liu, Q., Dong, X., Huang, K., and Chen, F. (2010). $\mathrm{Sr}_{2} \mathrm{Fe}_{4 / 3} \mathrm{Mo}_{2 / 3} \mathrm{O}_{6}$ as anodes for solid oxide fuel cells. J. Power Sources 195, 8071-8074. doi:10.1016/j. jpowsour.2010.07.036

Xiao, G., Liu, Q., Wang, S., Komvokis, V. G., Amiridis, M. D., Heyden, A., et al. (2012a). Synthesis and characterization of Mo-doped $\mathrm{SrFeO}_{3}$-delta as cathode materials for solid oxide fuel cells. J. Power Sources 202, 63-69. doi:10.1016/j. jpowsour.2011.11.021

Xiao, G., Liu, Q., Nuansaeng, S., and Chen, F. (2012b). $\mathrm{Sr}_{2} \mathrm{Fe}_{1+x} \mathrm{Mo}_{1-x} \mathrm{O}_{6}-\delta$ as anode materials for solid oxide fuel cells. ECS Trans. 45, 355-362. doi:10.1149/1. 3701327

Xiao, G., Jin, C., Liu, Q., Heyden, A., and Chen, F. (2012c). Ni modified ceramic anodes for solid oxide fuel cells. J. Power Sources 201, 43-48. doi:10.1016/j. jpowsour.2011.10.103

Xiao, G., Liu, Q., Zhao, F., Zhang, L., Xia, C., and Chen, F. (2011a). $\mathrm{Sr}_{2} \mathrm{Fe}_{1.5} \mathrm{Mo}_{0.5} \mathrm{O}_{6}$ as cathodes for intermediate-temperature solid oxide fuel cells with $\mathrm{La}_{0.8} \mathrm{Sr}_{0.2} \mathrm{Ga}_{0.87} \mathrm{Mg}_{0.13} \mathrm{O}_{3}$ electrolyte. J. Electrochem. Soc. 158, B455-B460. doi:10.1149/1.3556085

Xiao, G., Dong, X., Huang, K., and Chen, F. (2011b). Synthesis and characterizations of A-site deficient perovskite $\mathrm{Sr}_{0.9} \mathrm{Ti}_{0.8-x} \mathrm{Ga}_{x} \mathrm{Nb}_{0.2} \mathrm{O}_{3}$. Mater. Res. Bull. 46, 57-61. doi:10.1016/j.materresbull.2010.09.044

Xiao, G., Nuansaeng, S., Zhang, L., Suthirakun, S., Heyden, A., Loye, H.-C. Z., et al. (2013). Enhanced reducibility and conductivity of $\mathrm{Na} / \mathrm{K}$-doped $\mathrm{SrTi}_{0.8} \mathrm{Nb}_{0.2} \mathrm{O}_{3}$. J. Mater. Chem. A 1, 10546-10552. doi:10.1039/c3ta11631j

Xiao, G., Wang, S., Lin, Y., Yang, Z., Han, M., and Chen, F. (2014). Ni-doped Sr2Fe1.5Mo0.5O6- $\delta$ as anode materials for solid oxide fuel cells. J. Electrochem. Soc. 161, F305-F310. doi:10.1149/2.061403jes

Yang, C., Yang, Z., Jin, C., Xiao, G., Chen, F., and Han, M. (2012). Sulfur-tolerant redox-reversible anode material for direct hydrocarbon solid oxide fuel cells. Adv. Mater. Weinheim 24, 1439-1443. doi:10.1002/adma.201104852

Yoon, K. J., Coyle, C. A., and Marina, O. A. (2011). Doped yttrium chromite-ceria composite as a redox-stable and sulfur-tolerant anode for solid oxide fuel cells. Electrochem. Commun. 13, 1400-1403. doi:10.1016/j.elecom.2011.08.025

Zhang, L. L., Zhou, Q. J., He, Q. A., and He, T. M. (2010). Double-perovskites $\mathrm{A}(2) \mathrm{FeMoO}(6$-delta) $(\mathrm{A}=\mathrm{Ca}, \mathrm{Sr}, \mathrm{Ba})$ as anodes for solid oxide fuel cells. J. Power Sources 195, 6356-6366. doi:10.1016/j.jpowsour.2010.04.021

Zhang, Y. X., Sun, Q., Xia, C. R., and Ni, M. (2013). Geometric properties of nanostructured solid oxide fuel cell electrodes. J. Electrochem. Soc. 160, F278-F289. doi:10.1149/2.057303jes

Zhang, Y. X., and Xia, C. R. (2010). A particle-layer model for solid-oxidefull-cell cathodes with different structures. J. Power Sources 195, 4206-4212. doi:10.1016/j.jpowsour.2009.12.114

Zhu, W. Z., and Deevi, S. C. (2003a). Development of interconnect materials for solid oxide fuel cells. Mater. Sci. Eng. A Struct. Mater. 348, 227-243. doi:10.1016/S0921-5093(02)00736-0 
Zhu, W. Z., and Deevi, S. C. (2003b). A review on the status of anode materials for solid oxide fuel cells. Mater. Sci. Eng. A Struct. Mater. 362, 228-239. doi:10.1016/S0921-5093(03)00620-8

Zhu, X., Lu, Z., Wei, B., Chen, K. F., Liu, M. L., Huang, X. Q., et al. (2009). Enhanced performance of solid oxide fuel cells with $\mathrm{Ni} / \mathrm{CeO}(2)$ modified $\mathrm{La}(0.75) \mathrm{Sr}(0.25) \mathrm{Cr}(0.5) \mathrm{Mn}(0.5) \mathrm{O}(3$-delta) anodes. J. Power Sources 190, 326-330. doi:10.1016/j.jpowsour.2009.01.035

Conflict of Interest Statement: The authors declare that the research was conducted in the absence of any commercial or financial relationships that could be construed as a potential conflict of interest.
Received: 02 May 2014; paper pending published: 13 May 2014; accepted: 22 May 2014; published online: 06 June 2014.

Citation: Xiao G and Chen F (2014) Redox stable anodes for solid oxide fuel cells. Front. Energy Res. 2:18. doi: 10.3389/fenrg.2014.00018

This article was submitted to Fuel Cells, a section of the journal Frontiers in Energy Research.

Copyright (c) 2014 Xiao and Chen. This is an open-access article distributed under the terms of the Creative Commons Attribution License (CC BY). The use, distribution or reproduction in other forums is permitted, provided the original author(s) or licensor are credited and that the original publication in this journal is cited, in accordance with accepted academic practice. No use, distribution or reproduction is permitted which does not comply with these terms. 